NATIONAL LABORATORY

\title{
Low-Enriched Uranium Fuel Conversion Activities for the High Flux Isotope Reactor, Annual Report for FY 2011
}

\section{March 2012}

Prepared by

D. G. Renfro

D. Chandler

D. H. Cook

J. D. Freels

F. P. Griffin

G. Ilas

R. T. Primm III

J. D. Sease
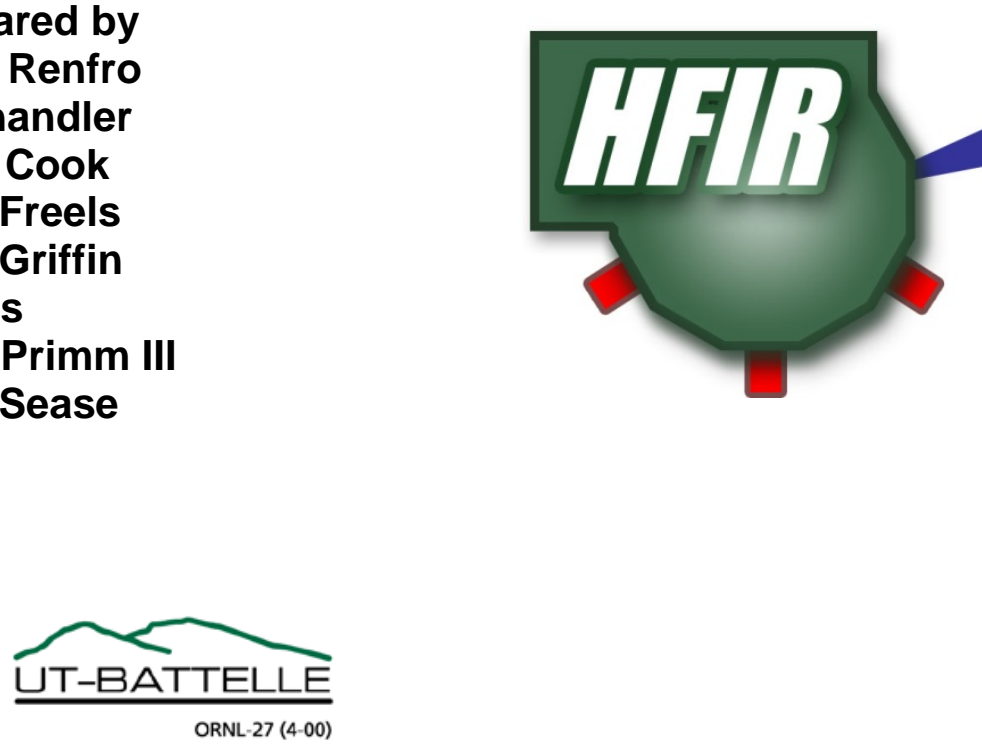


\title{
DOCUMENT AVAILABILITY
}

Reports produced after January 1, 1996, are generally available free via the U.S. Department of Energy (DOE) Information Bridge.

Web site http://www.osti.gov/bridge

Reports produced before January 1, 1996, may be purchased by members of the public from the following source.

\author{
National Technical Information Service \\ 5285 Port Royal Road \\ Springfield, VA 22161 \\ Telephone 703-605-6000 (1-800-553-6847) \\ TDD 703-487-4639 \\ Fax 703-605-6900 \\ E-mail info@ntis.fedworld.gov \\ Web site http://www.ntis.gov/support/ordernowabout.htm
}

Reports are available to DOE employees, DOE contractors, Energy Technology Data Exchange (ETDE) representatives, and International Nuclear Information System (INIS) representatives from the following source.

Office of Scientific and Technical Information

P.O. Box 62

Oak Ridge, TN 37831

Telephone 865-576-8401

Fax 865-576-5728

E-mail reports@osti.gov

Web site http://www.osti.gov/contact.html

This report was prepared as an account of work sponsored by an agency of the United States Government. Neither the United States government nor any agency thereof, nor any of their employees, makes any warranty, express or implied, or assumes any legal liability or responsibility for the accuracy, completeness, or usefulness of any information, apparatus, product, or process disclosed, or represents that its use would not infringe privately owned rights. Reference herein to any specific commercial product, process, or service by trade name, trademark, manufacturer, or otherwise, does not necessarily constitute or imply its endorsement, recommendation, or favoring by the United States Government or any agency thereof. The views and opinions of authors expressed herein do not necessarily state or reflect those of the United States Government or any agency thereof. 


\title{
LOW-ENRICHED URANIUM FUEL CONVERSION ACTIVITIES FOR THE HIGH FLUX ISOTOPE REACTOR, ANNUAL REPORT FOR FY 2011
}

\author{
D. G. Renfro \\ D. Chandler \\ D. H. Cook \\ J. D. Freels \\ F. P. Griffin \\ G. Ilas \\ R. T. Primm III \\ J. D. Sease
}

Date Published: March 2012

\footnotetext{
Prepared by

OAK RIDGE NATIONAL LABORATORY

Oak Ridge, Tennessee 37831-6283

managed by

UT-BATTELLE, LLC

for the

U.S. DEPARTMENT OF ENERGY

under contract DE-AC05-00OR22725
} 



\section{CONTENTS}

Page

LIST OF FIGURES

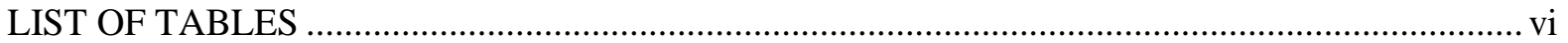

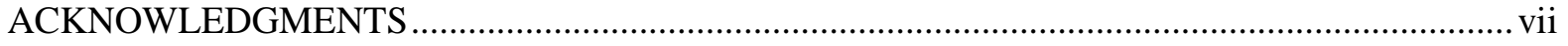

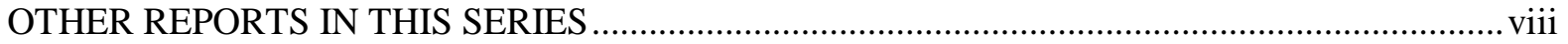

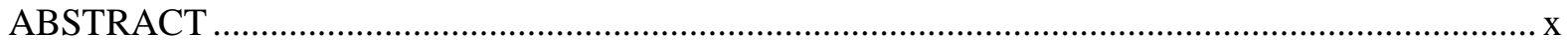

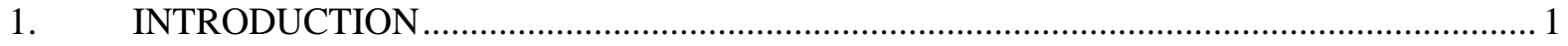

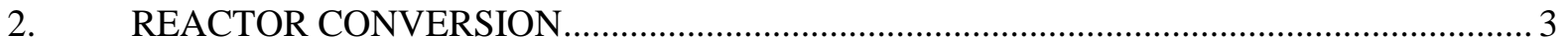

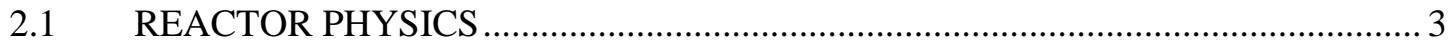

2.1.1 New Monte Carlo — Based Depletion Models with VESTA/MCNP ............ 3

2.1.2 Performance and Safety Parameters for the HFIR LEU Core......................... 4

2.1.2.1 Neutron flux .................................................................................. 4

2.1.2.2 Fission density distribution ........................................................ 5

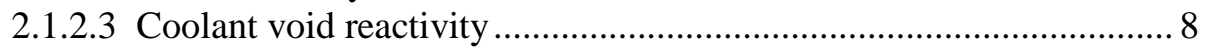

2.1.2.4 Flux trap void reactivity ..................................................... 8

2.1.2.5 Effective delayed neutron fraction ....................................... 9

2.1.2.6 Isotopic composition in spent fuel ................................................ 9

2.1.2.7 Decay heat in spent fuel ........................................................... 9

2.1.2.8 Power distributions for thermal hydraulic analyses ........................ 11

2.1.3 Communication with HFIR Researchers................................................ 11

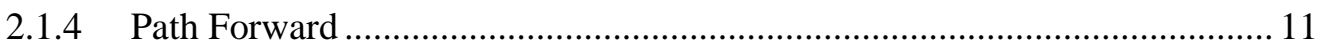

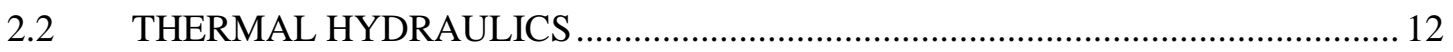

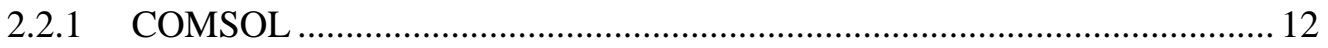

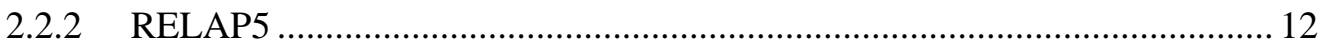

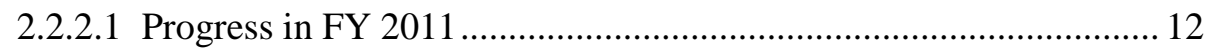

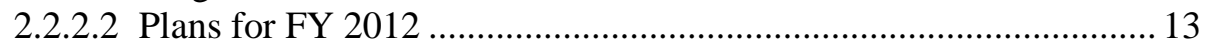

2.3 FISSION PRODUCT RELEASE AND TRANSPORT AND

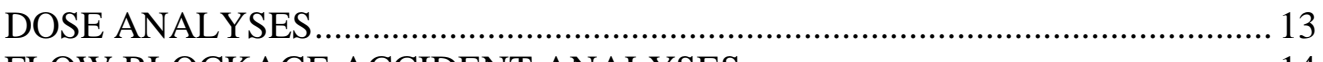

2.4 FLOW BLOCKAGE ACCIDENT ANALYSES ................................................. 14

2.5 OREGON STATE UNIVERSITY HYDRAULIC TESTING …................................. 15

2.6 INVOLUTE PLATE THERMAL DEFLECTION SEPARATE

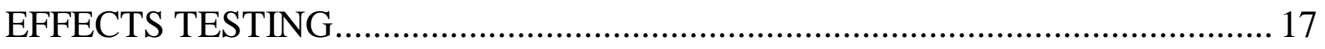

2.7 HFIR LEU FUEL CONVERSION SCHEDULE............................................... 19

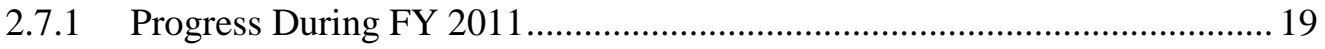

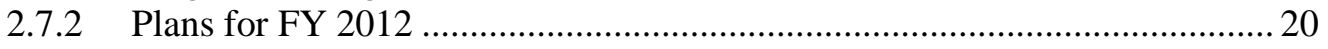

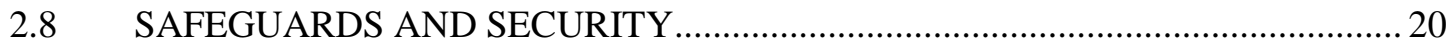

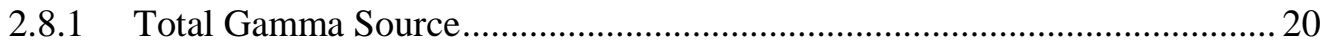

2.8.2 Safeguards Category for LEU Fuel .......................................................... 21

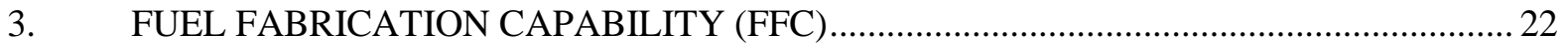

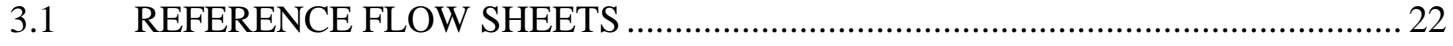

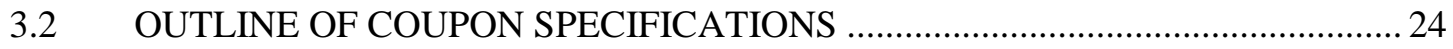

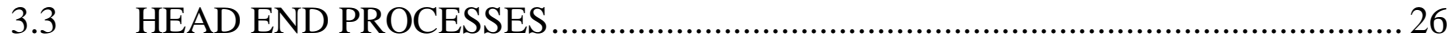




\section{CONTENTS (continued)}

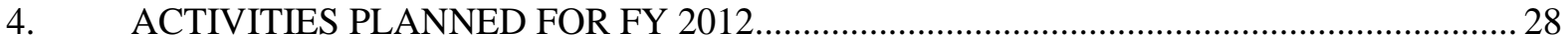

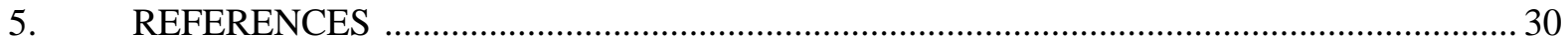

APPENDIX: METHODOLOGY FOR CALCULATING POWER DISTRIBUTIONS FOR USE

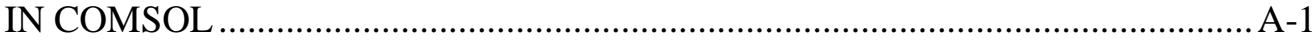




\section{LIST OF FIGURES}

Page

1. Variation of $\mathrm{k}_{\mathrm{eff}}$ with the reduction of water density in flux trap region ................................. 8

2. Decay heat for spent fuel — comparison of HEU cycle 400 and LEU cores ....................... 10

3. Photographs of Cheverton-Kelly test apparatus — side and end views ................................ 18

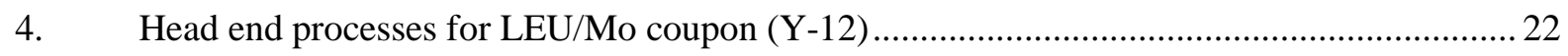

5. Flat plate fabrication processes (B\&W NOG LEU-Mo Zr clad sheets)................................ 23

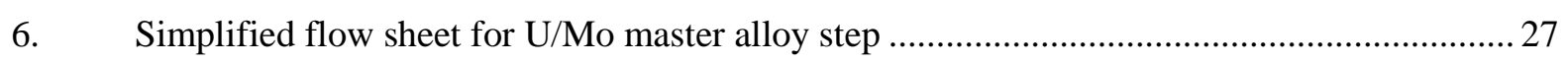





\section{LIST OF TABLES}

Page

1. Neutron flux at BOC — comparison of HEU cycle 400 and LEU cores ............................... 5

2. Neutron flux at EOC — comparison of HEU cycle 400 and LEU cores ................................ 5

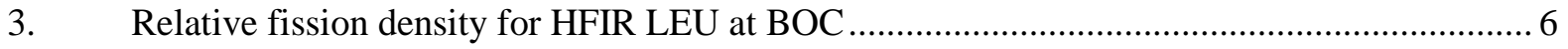

4. Relative fission density for HFIR LEU at EOC ….......................................................... 7

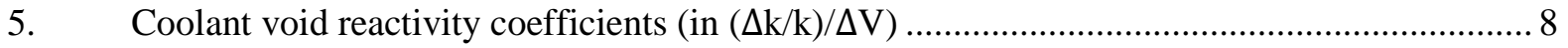

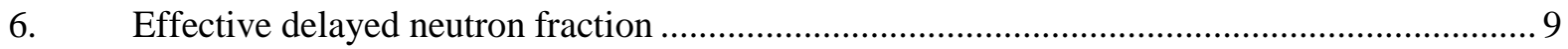

7. Major actinides inventory (in grams) for HEU and LEU cores at EOC................................ 9

8. Decay heat for spent fuel—comparison of HEU cycle 400 and LEU cores ......................... 10

9. HFIR accident categories and bounding sequence that involve fuel damage ........................ 13

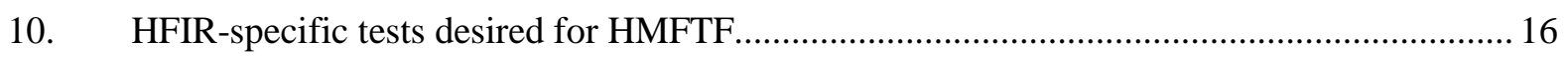

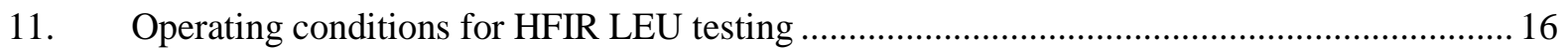

12. Proposed interfacing links between HFIR LEU conversion schedule (9/30/2011) and GTRI conversion program.......................................................................................... 19

13. Outline of process specification requirements U/Mo coupons............................................ 24

14. Outline of chemical and physical specifications for U/Mo coupons..................................... 25 



\section{ACKNOWLEDGMENTS}

The authors would like to acknowledge that the support for this project was provided by the Global Threat Reduction Initiative (GTRI), Reduced Enrichment for Research and Test Reactors program (RERTR), Nuclear National Security Administration, U. S. Department of Energy (DOE). The DOE program manager was Christopher C. Landers, the Argonne National Laboratory RERTR Reactor Conversion program manager was Dr. John Stevens, and the Fuel Fabrication Capability program manager was Dr. Douglas Burkes of the Pacific Northwest National Laboratory. The authors also acknowledge the technical review of this document performed by Dr. Kevin A. Smith, Research Reactors Division, Oak Ridge National Laboratory. Finally, the authors wish to thank Mary Wells for document preparation and editing of this report. 



\section{OTHER REPORTS IN THIS SERIES}

R. T. Primm III, R. J. Ellis, J. C. Gehin, D. L. Moses, J. L. Binder, and N. Xoubi, Assumptions and Criteria for Performing a Feasibility Study of the Conversion of the High Flux Isotope Reactor Core to Use Low-Enriched Uranium Fuel, ORNL/TM-2005/269, February 2006.

R. T. Primm III, R. J. Ellis, J. C. Gehin, K. T. Clarno, K. A. Williams, and D. L. Moses, Design Study for a Low-Enriched Uranium Core for the High Flux Isotope Reactor, Annual Report for FY 2006, ORNL/TM-2006/136, November 2006.

J. D. Sease, R. T. Primm III, and J. H. Miller, Conceptual Process for the Manufacture of Lowenriched Uranium/Molybdenum Fuel for the High Flux Isotope Reactor, ORNL/TM-2007/39, September 2007.

R. T. Primm III, R. J. Ellis, J. C. Gehin, G. Ilas, J. H. Miller, and J. D. Sease, Design Study for a LowEnriched Uranium Core for the High Flux Isotope Reactor, Annual Report for FY 2007, ORNL/TM2007/45, November 2007.

D. Chandler, R. T. Primm, III, and G. I. Maldonado, Validating MCNP for LEU Fuel Design via Power Distribution Comparisons, ORNL/TM-2008/126, November 2008.

Lee Tschaepe, Arthur E. Ruggles, James D. Freels, and R. T. Primm, III, Evaluation of HFIR LEU Fuel Using the COMSOL Multiphysics Platform, ORNL/TM-2008/188, March 2009.

C. Galvez Velit, R. T. Primm III, and J. C. Gehin, Partial Safety Analysis for a Reduced Uranium Enrichment Core for the High Flux Isotope Reactor, ORNL/TM-2007/226, April 2009.

R. T. Primm III, D. Chandler, G. Ilas, B. C. Jolly, J. H. Miller, and J. D. Sease, Design Study for a Low-Enriched Uranium Core for the High Flux Isotope Reactor, Annual Report for FY 2008, ORNL/TM-2009/87, March 2009.

D. Chandler, R. T. Primm, III, and G. I. Maldonado, Validation of a Monte Carlo Based Depletion Methodology with HFIR Post-Irradiation Examination Data, ORNL/TM-2009/123, July 2009.

G. Ilas and R. T. Primm, III, Fuel Grading Study on a Low-Enriched Uranium Fuel Design for the High Flux Isotope Reactor, ORNL/TM-2009/223, November 2009, revised and reissued as ORNL/TM-2009/223/R1, March 2010.

Tracey Guida and R. T. Primm, III, Establishing a Cost Basis for Converting the High Flux Isotope Reactor from High Enriched to Low Enriched Uranium Fuel, ORNL/TM-2009/311, February 2010.

R. T. Primm, III, D. Chandler, J. D. Freels, T. Guida, G. Ilas, B. C. Jolly, J. H. Miller, and J. D. Sease, Design Study for a Low-Enriched Uranium Core for the High Flux Isotope Reactor, Annual Report for FY 2009, ORNL/TM-2009/313, February 2010.

J. D. Freels, I. T. Bodey, R. V. Arimilli, and K. T. Lowe, Two Dimensional Thermal Hydraulic Analysis and Benchmark in Support of HFIR LEU Conversion Using COMSOL, ORNL/TM-2010/18, September 2010. 
R. T. Primm, III, D. L. Pinkston, J. D. Sease, and D. G. Renfro, Establishing Specifications for Low Enriched Uranium Fuel Operations Conducted Outside the High Flux Isotope Reactor Site, ORNL/TM-2010/241, September 2010.

G. Ilas and R. T. Primm, III, Low Enriched Uranium Fuel Design with Two-Dimensional Grading for the High Flux Isotope Reactor, ORNL/TM-2010/318, April 2011.

R. T. Primm, III, D. H. Cook, J. D. Freels, G. Ilas, B. C. Jolly, J. H. Miller, D. L. Pinkston, D. G. Renfro, J. D. Sease, Design Study for a Low-Enriched Uranium Core for the High Flux Isotope Reactor, Annual Report for FY 2010, ORNL/TM-2011/6, February 2011.

J. D. Freels, I. T. Bodey, R. V. Arimilli, F. G. Curtis, K. Ekici, P. K. Jain, Preliminary Multiphysics Analyses of HFIR LEU Fuel Conversion using COMSOL, ORNL/TM-2011/007, June 2011 


\begin{abstract}
This report describes progress made during FY 2011 in ORNL activities to support converting the High Flux Isotope Reactor (HFIR) from high-enriched uranium (HEU) fuel to low-enriched uranium (LEU) fuel. Conversion from HEU to LEU will require a change in fuel form from uranium oxide to a uranium-molybdenum (UMo) alloy. With an increase in reactor power to $100 \mathrm{MW}$, neutronics calculations indicate that the HFIR can be operated with LEU fuel with no degradation in performance to users from the current levels achieved with HEU fuel. Studies are continuing to demonstrate that the fuel thermal safety margins can be preserved following conversion. Studies are also continuing to update other aspects of the reactor steady state operation and accident response for the effects of fuel conversion. Technical input has been provided to Oregon State University in support of their hydraulic testing program. The HFIR conversion schedule was revised and provided to the GTRI program. In addition to HFIR conversion activities, technical support was provided directly to the Fuel Fabrication Capability program manager.
\end{abstract}





\section{INTRODUCTION}

Activities to support the conversion of the High Flux Isotope Reactor (HFIR) from high-enriched uranium (HEU) fuel to low-enriched uranium (LEU) fuel were conducted by ORNL according to the scope of work originally documented in the FY 2011 work package ${ }^{1}$ as listed below and later internally modified to acknowledge mid-year budget reductions. Descriptions of progress in each reactor conversion topical area are presented in separate sections of this annual report as noted in the inserts into the scope of work below. Support for the Fuel Fabrication Capability program is also described. The final section of this report discusses activities planned for FY 2012.

Scope of Work [from ref. 1]:

ORNL will continue to perform detailed design and safety analyses required to convert the HFIR from the use of HEU fuel to LEU fuel. Project Management during FY 2011 will focus on the creation of an integrated plan for the conversion, including the proposed phased approach to 100 MW operation with LEU fuel [2.7]. The interface to safety oversight, per DOE Order 1189, will be formalized during FY 2011 [deferred to FY 2012]. HFIR engineering staff will continue work on neutronics, thermal-hydraulics, transients, and other safety analyses that are needed for conversion.

1. Complete LEU impact study to update and maintain HFIR conversion schedule integrated with conversion program schedule. Continue HFIR conversion coordination and interface with conversion program [2.7].

2. Establish integrated DOE SC/ORNL LEU fuel conversion team and develop safety design strategy [deferred to FY 2012].

3. Continue neutronics analyses [2.1]

a. in support of ANL peer review of ORNL analyses

b. to confirm with researchers that any impacts on flux/spectra of neutron beams are understood

c. to assess any impacts on reactor vessel embrittlement monitoring [deferred to FY 2012].

d. to provide input for COMSOL TH analysis of optimized fuel; e.g., power profile without axial grading, power profile without burnable poison, and sensitivity of power profile to radial grading [deferred to FY 2012].

4. Continue core multiphysics (TH/structural mechanics) analyses with COMSOL [2.2.1]

a. to develop and validate 3-D TH/structural mechanics model of HFIR fuel elements

b. to provide input (e.g., hot spot factor, structural mechanics effects) to support steady-state and transient analyses for SAR Chapters 4 and 15 including integration with updated RELAP5 model.

5. Complete plant RELAP5 consolidated input model and documentation, including preparations to apply COMSOL input [2.2.2].

6. Continue support of flow testing at Oregon State, including design of HFIR test insert [2.5].

7. Establish requirements for fuel plate deflection testing for thermal and pressure effects [2.6].

8. Develop methodology for revised fission product release and transport and offsite dose analyses [2.3]. 
9. Scope SAR Chapter 15 revisions for non-RELAP-analyzed accidents [2.4].

10. Study safeguards and security issues [2.8].”

“Deliverables [from ref. 1]:

1. Annual report of work conducted during FY 2010; due 1/31/11; [ORNL/TM-2011/6 issued 2/11].

2. ORNL Topical Report of physics/thermal hydraulics studies for the reference (axially graded) LEU fuel design for subsequent ANL review; due 1/31/11; [ORNL/TM-2010/318 issued 3/11].

3. ORNL Topical Report on multiphysics model development for LEU fuel; due 1/31/11; [ORNL/TM-2011/7 issued 6/11].

4. ORNL Topical Report on Conversion Project Phase Scope, Schedule and Budget; due 3/15/11; [rescoped from topical report to MS Project schedule file submitted to GTRI program 9/11].

5. ORNL Topical Report on review of original HFIR HEU fuel flow and plate deflection testing and plans for LEU testing; due 6/15/11; [deferred to FY 2012].

6. Progress Report on FY11 Activities; due 9/15/11; [rescheduled to FY 2012]. 


\section{REACTOR CONVERSION}

\subsection{REACTOR PHYSICS}

The computational models developed during FY 2010 to search for an LEU fuel design that would meet the requirements for the conversion to LEU have been finalized in FY 2011. These models and the results obtained with them have been documented in an ORNL report published in April 2011. ${ }^{2}$ Two calculation reports ${ }^{3,4}$ complementary to the ORNL report ${ }^{1}$ have been developed to present in detail the calculations and the models used. These two calculation reports were provided to Argonne National Laboratory (ANL) for an external independent review. Estimates of relevant reactor performance parameters for the HFIR LEU fuel core have been compared with the corresponding data for the currently operating HEU fuel core. ${ }^{2}$ These parameters have been listed along with the corresponding data as included in the current HFIR [HEU] Safety Analysis Report (SAR) ${ }^{5}$ to facilitate an "at a glance" comparison between the HEU and the LEU cores for physics and thermal hydraulics parameters that will need to be changed when the SAR is updated for LEU fuel.

A summary of the reactor physics analyses carried out in FY 2011 is presented in this section, highlighting the new findings as compared to studies reported in previous years. The results obtained indicated that the LEU fuel design would maintain the current performance of the HFIR with respect to the neutron flux to the central target region, reflector, and beam tube locations under the assumption that the operating power for the reactor fueled with LEU can be increased from the current value of $85 \mathrm{MW}$ to $100 \mathrm{MW}$.

\subsubsection{New Monte Carlo-Based Depletion Models With VESTA/MCNP}

The development of a new three-dimensional (3-D) Monte Carlo-based depletion model for the HFIR LEU core that started in FY 2010 has been completed in FY 2011. This model was used to perform burnup simulations of the HFIR LEU core and served as an engine in the search of an optimal fuel design and core configuration details. The new depletion model is based on the computational tool VESTA ${ }^{6}$ developed at Institut de Radioprotection et de Sûreté Nucléaire (IRSN)—Institute for Radiological Protection and Nuclear Safety-in France, which couples the Monte Carlo neutron-photon transport code $\mathrm{MCNP}^{7}$ and the point depletion and decay code ORIGEN 2.2. ${ }^{8}$ Previously, depletion analysis for HFIR had been carried out ${ }^{9}$ with the Monte Carlo-based depletion tool ALEPH ${ }^{10}$ developed by SCK/CEN in Belgium. Later, since VESTA became available, the latter has been used because of its modeling capabilities of importance to HFIR analyses, such as: (1) explicit simulation of the control element movement during the cycle; (2) depletion of nonfissile materials, which in the case of HFIR makes possible to account for the irradiation of control elements, beryllium reflector, or nonfissile targets during the reactor cycle; and (3) availability of ENDF/B-VII cross section data.

The use of the new depletion tool VESTA facilitated improvements to the HFIR depletion model, such as making it possible to account for the irradiation of nonfissile materials (e.g., control elements) during the reactor cycle. In addition, VESTA can be used with an extended set of nuclear cross sections, including those that are based on the most recent ENDF/B-VII nuclear data evaluations. Nuclear data for individual molybdenum isotopes in the ENDF/B-VII files should provide a better treatment of these isotopes than in previous studies that used ENDF/B-VI data. As molybdenum is a major component (10 wt \%) of the considered U-Mo LEU fuel, the use of the best available cross section data for its isotopes is highly desirable.

Compared to depletion models used in previous years, the HFIR LEU model used in FY $2011^{2}$ includes the following changes: 
a) addition of a zirconium interlayer between the U-10Mo foil and the filler region of the fuel plate;

b) accounting for the irradiation history of the materials in the control elements;

c) changing the quantity of boron in the inner fuel element for optimizing the power distribution in the core;

d) using a control element movement ("control element withdrawal curve”) that would minimize the variation of the $\mathrm{k}_{\mathrm{eff}}$ during the cycle.

Revision of the depletion model with respect to the control region in the HFIR model consisted of changing the composition of the materials in this region to account for the irradiation history of the control elements (CEs). Each of the two CEs in HFIR includes three axial regions with different neutron absorption properties: a strong neutron-absorber region containing europium oxide dispersed in an aluminum matrix, a moderate neutron-absorber region with tantalum particles in an aluminum matrix, and a region of perforated aluminum. The CEs in HFIR are present in the core for a large number of reactor cycles, for periods of time as large as a thousand days of irradiation. An outer element is removed from the core after six irradiation cycles (typically) for maintenance and inserted back in the core after a period of decay time. During irradiation, the composition of the materials changes due to neutron interactions, therefore leading to a change in the absorption properties (cross sections) of these materials. A methodology has been developed and validated ${ }^{11}$ to perform fast simulations of the HFIR control elements' irradiation history with the purpose of determining their material composition at a given time. This methodology has been applied ${ }^{2}$ to determine the material compositions of the CEs present in the reactor at the beginning of cycle (BOC) 400. These material compositions for the control elements at BOC-400 have been also used for the HFIR LEU core model at BOC.

A new VESTA depletion model has been also completed for the HFIR HEU core to serve as a basis for the design of the LEU fuel core. This depletion model is based on a revised ${ }^{2,12}$ MCNP model for Cycle 400. Based on this VESTA model, relevant reactor performance and safety parameters were calculated as a function of the irradiation time for the HFIR HEU core. The results obtained with this model served as reference for assessing the performance of the proposed LEU fuel, as both HEU and LEU core models use the same methodologies and cross section libraries.

\subsubsection{Performance and Safety Parameters for the HFIR LEU Core}

Relevant performance and safety parameters for the HFIR LEU core and HEU core were calculated at the BOC and end of cycle (EOC) states and other intermediate times during the cycle based on results of VESTA depletion simulations. As most of these parameters are not directly provided by VESTA, various approaches were used to determine them. VESTA outputs only isotopic composition as a function of the burnup step and saves MCNP input and output files that correspond to each burnup step used in the depletion simulation. Results for some of these parameters are summarized in this section.

\subsubsection{Neutron flux}

The neutron flux level is one of the key parameters for characterizing the core performance. Three-group flux data estimated based on MCNP flux tallies at BOC and EOC, respectively, are presented in Tables 1 and 2 for the following locations: central target in flux trap, reflector at $27.5 \mathrm{~cm}$ radius, cold source edge at $35 \mathrm{~cm}$ radius, reflector outer edge at $54.7 \mathrm{~cm}$, and targets in the removable beryllium reflector. The relative standard deviation for the tallied flux is less than $1 \%$ in all cases. The energy structure for the shown three-group data is thermal $(<0.625 \mathrm{eV})$, epithermal $(0.625 \mathrm{eV}-100 \mathrm{keV})$, and fast $(100 \mathrm{keV}-$ $20 \mathrm{MeV}$ ). As observed, the fluxes corresponding to the LEU core at $100 \mathrm{MW}$ are in good agreement with those calculated for the HEU core at $85 \mathrm{MW}$. 
Table 1. Neutron flux at BOC - comparison of HEU cycle 400 and LEU cores

\begin{tabular}{|c|c|c|c|c|}
\hline Location & Fuel & $\begin{array}{l}\text { Thermal flux } \\
\left(\mathbf{n} / \mathrm{cm}^{2} \mathbf{s}\right)\end{array}$ & $\begin{array}{c}\text { Epithermal } \\
\text { flux } \\
\left(\mathbf{n} / \mathbf{c m}^{2} \mathbf{s}\right)\end{array}$ & $\begin{array}{l}\text { Fast flux } \\
\left(\mathbf{n} / \mathrm{cm}^{2} \mathbf{s}\right)\end{array}$ \\
\hline $\begin{array}{l}\text { Central target } \\
\mathrm{r}=0 \mathrm{~cm}\end{array}$ & $\begin{array}{l}\text { HEU } \\
\text { LEU }\end{array}$ & $\begin{array}{l}2.2 \times 10^{15} \\
2.3 \times 10^{15}\end{array}$ & $\begin{array}{l}1.3 \times 10^{15} \\
1.3 \times 10^{15}\end{array}$ & $\begin{array}{l}1.1 \times 10^{15} \\
1.2 \times 10^{15}\end{array}$ \\
\hline $\begin{array}{l}\text { Cold source edge } \\
\mathrm{r}=35 \mathrm{~cm}\end{array}$ & $\begin{array}{l}\text { HEU } \\
\text { LEU }\end{array}$ & $\begin{array}{l}6.5 \times 10^{14} \\
7.5 \times 10^{14}\end{array}$ & $\begin{array}{l}2.4 \times 10^{14} \\
2.8 \times 10^{14}\end{array}$ & $\begin{array}{l}9.3 \times 10^{13} \\
1.1 \times 10^{14}\end{array}$ \\
\hline $\begin{array}{l}\text { Reflector } \\
\mathrm{r}=27 \mathrm{~cm}\end{array}$ & $\begin{array}{l}\text { HEU } \\
\text { LEU }\end{array}$ & $\begin{array}{l}5.6 \times 10^{14} \\
6.3 \times 10^{14}\end{array}$ & $\begin{array}{l}6.3 \times 10^{14} \\
7.6 \times 10^{14}\end{array}$ & $\begin{array}{l}4.1 \times 10^{14} \\
4.8 \times 10^{14}\end{array}$ \\
\hline
\end{tabular}

Table 2. Neutron flux at EOC - comparison of HEU cycle 400 and LEU cores

\begin{tabular}{lcccc}
\hline \multicolumn{1}{c}{ Location } & Fuel & $\begin{array}{c}\text { Thermal flux } \\
\left(\mathbf{n} / \mathbf{c m}^{2} \mathbf{s}\right)\end{array}$ & $\begin{array}{c}\text { Epithermal } \\
\text { flux } \\
\left(\mathbf{n} / \mathbf{c m}^{2} \mathbf{s}\right)\end{array}$ & $\begin{array}{c}\text { Fast flux } \\
\left(\mathbf{n} / \mathbf{c m}^{2} \mathbf{s}\right)\end{array}$ \\
\hline $\begin{array}{l}\text { Central target } \\
\mathrm{r}=0 \mathrm{~cm}\end{array}$ & HEU & $2.2 \times 10^{15}$ & $1.1 \times 10^{15}$ & $9.5 \times 10^{14}$ \\
& LEU & $2.5 \times 10^{15}$ & $1.2 \times 10^{15}$ & $1.1 \times 10^{15}$ \\
$\begin{array}{l}\text { Cold source edge } \\
\mathrm{r}=35 \mathrm{~cm}\end{array}$ & HEU & $8.3 \times 10^{14}$ & $2.4 \times 10^{14}$ & $9.4 \times 10^{13}$ \\
& LEU & $8.4 \times 10^{14}$ & $2.7 \times 10^{14}$ & $1.0 \times 10^{14}$ \\
$\begin{array}{l}\text { Reflector } \\
\mathrm{r}=27 \mathrm{~cm}\end{array}$ & HEU & $8.1 \times 10^{14}$ & $6.5 \times 10^{14}$ & $4.1 \times 10^{14}$ \\
\hline & LEU & $7.2 \times 10^{14}$ & $7.3 \times 10^{14}$ & $4.6 \times 10^{14}$ \\
\hline
\end{tabular}

\subsubsection{Fission density distribution}

The relative fission density data were calculated in the two fuel elements based on flux and fission density tallies in MCNP for BOC, EOC, and at selected intermediate times during the irradiation cycle. When used as input for the thermal hydraulics analysis with the HFIR legacy code HSSHTC, the corresponding operating power was obtained as 102.61 MW at BOC and 107.07 MW at EOC. ${ }^{2}$ This represents a nominal design case rather than the more thermally limiting safety basis cases that will be analyzed later using the new COMSOL code. The relative fission density data for the LEU core at BOC and EOC are listed in Tables 3 and 4. 
Table 3. Relative fission density for HFIR LEU at BOC

\begin{tabular}{|c|c|c|c|c|c|c|c|c|c|c|c|c|c|c|c|c|c|}
\hline \multirow{2}{*}{$\begin{array}{l}\text { Axial } \\
\text { region \# }\end{array}$} & \multicolumn{8}{|c|}{ IFE } & \multicolumn{9}{|c|}{ OFE } \\
\hline & $\mathrm{r}=1^{a}$ & $\mathrm{r}=2$ & $r=3$ & $r=4$ & $r=5$ & $r=6$ & $r=7$ & $r=8$ & $r=1$ & $r=2$ & $r=3$ & $r=4$ & $r=5$ & $r=6$ & $r=7$ & $r=8$ & $\mathrm{r}=9$ \\
\hline 1 & 994 & 311 & 1.564 & .561 & 1.483 & 1.339 & 1.140 & 1.144 & 1.215 & 1.239 & 1.388 & 1.330 & 1.158 & 1.042 & .791 & .470 & .351 \\
\hline 2 & & & & & & & & & & & & 798 & & & 34 & & \\
\hline 3 & 89 & 850 & 801 & 731 & 737 & 825 & 833 & 850 & .888 & 859 & 798 & 636 & 530 & .503 & .443 & 322 & .265 \\
\hline 4 & 0.762 & 807 & .742 & 0.680 & 692 & 779 & 0.778 & & 0.818 & 800 & 757 & 612 & 511 & .488 & .434 & 316 & .260 \\
\hline 5 & 0.775 & 0.827 & 0.771 & 0.710 & 0.724 & 0.795 & 0.775 & 0.789 & 0.807 & 0.796 & 0.781 & 0.649 & .545 & 0.522 & 0.468 & 0.339 & 0.273 \\
\hline 6 & 889 & 0.952 & .901 & 0.838 & 851 & 911 & 0.867 & 876 & 0.903 & 905 & 911 & 777 & 661 & 648 & 618 & .491 & 11 \\
\hline 7 & 083 & 163 & 101 & 1.029 & 1.045 & 1.112 & 1.052 & 066 & 1.092 & 098 & 121 & .966 & 832 & 839 & 853 & .731 & 626 \\
\hline 8 & 1.298 & 1.395 & 1.324 & 1.240 & 1.261 & 1.345 & 1.273 & 1.287 & 1.321 & 332 & 68 & 1.193 & 044 & 1.078 & 168 & .074 & 44 \\
\hline 9 & 1.406 & 1.510 & 1.434 & 1.345 & 1.373 & 1.464 & 1.385 & & 1.448 & 456 & 498 & 1.318 & 169 & 1.248 & .474 & 486 & \\
\hline 1 & & & 1.442 & 1.350 & 1.377 & 1.471 & 1.393 & .411 & 1.456 & 1.467 & 504 & 1.326 & 177 & 1.265 & .508 & .538 & .397 \\
\hline 1 & 388 & 1.489 & 1.420 & 1.332 & 1.358 & 1.447 & 1.367 & 384 & 1.430 & 439 & 479 & 1.304 & 159 & 240 & .470 & 491 & 351 \\
\hline 12 & 1.256 & 1.348 & 1.282 & 1.201 & & 1.299 & 1.229 & & 1.277 & & & & & 1.029 & 101 & & 0.869 \\
\hline 13 & 1.020 & 1.092 & 1.033 & 0.961 & & 1.039 & 0.983 & & 1.021 & 1.026 & 1.043 & 0.901 & 0.776 & 0.772 & 0.774 & 0.651 & 0.554 \\
\hline 1 & .826 & 0.880 & 0.825 & 0.766 & 0.778 & 0.838 & 0.802 & & 0.835 & 0.834 & 0.834 & 0.703 & .593 & 0.575 & 0.528 & .399 & 0.328 \\
\hline 15 & 0.723 & 0.768 & 0.714 & 0.664 & 0.680 & 0.754 & 0.743 & 0.757 & 0.782 & 0.770 & 0.743 & 0.609 & 0.505 & 0.468 & 0.382 & 0.241 & 0.184 \\
\hline 16 & 0.712 & 0.779 & 0.711 & 0.700 & 0.715 & 0.732 & 0.689 & 0.692 & 0.722 & 0.750 & 0.765 & 0.645 & 0.540 & 0.488 & 0.381 & 0.230 & 0.165 \\
\hline 17 & 0.749 & 0.715 & 0.535 & 0.508 & 0.505 & 0.552 & 0.548 & 0.529 & 0.547 & 0.636 & 0.603 & 0.496 & 0.419 & 0.365 & 0.296 & 0.212 & 0.137 \\
\hline 18 & & & & 0.327 & & 0.360 & & & 0.4 & & & 0.275 & 0.236 & 0.201 & 0.166 & 0.140 & 0.131 \\
\hline 19 & 0.768 & 0.604 & 0.497 & 0.447 & 0.429 & 0.449 & 0.502 & 0.512 & 0.515 & 0.485 & 0.421 & 0.360 & 0.312 & 0.264 & 0.212 & 0.168 & 0.152 \\
\hline
\end{tabular}

${ }^{a} \mathrm{r}=\mathrm{n}$ denotes the radial region number; $\mathrm{n}$ varies from 1 to 8 for the IFE and from 1 to 9 for the OFE. 
Table 4. Relative fission density for HFIR LEU at EOC

\begin{tabular}{|c|c|c|c|c|c|c|c|c|c|c|c|c|c|c|c|c|c|}
\hline \multirow{2}{*}{$\begin{array}{c}\text { Axial } \\
\text { region \# }\end{array}$} & \multicolumn{8}{|c|}{ IFE } & \multicolumn{9}{|c|}{ OFE } \\
\hline & $r=1$ & $r=2$ & $r=3$ & $r=4$ & $r=5$ & $r=6$ & $r=7$ & $r=8$ & $r=1$ & $r=2$ & $r=3$ & $r=4$ & $r=5$ & $r=6$ & $\mathrm{r}=7$ & $r=8$ & $r=9$ \\
\hline 1 & 0.735 & 1.162 & 1.502 & 1.502 & 1.441 & 1.276 & 1.024 & .032 & 1.098 & 1.136 & 1.394 & 1.416 & 316 & 1.325 & 1.247 & 0.949 & 0.792 \\
\hline 2 & 698 & 004 & 090 & 991 & 968 & 989 & 892 & & & & 979 & .858 & 771 & 809 & 0.902 & 843 & 0.755 \\
\hline 3 & 0.668 & 0.888 & 0.868 & 0.753 & 0.752 & 0.832 & 0.794 & 0.820 & 0.852 & 0.826 & 0.803 & 0.665 & 0.589 & 0.639 & 0.793 & 0.818 & 0.752 \\
\hline 4 & 0.657 & 0.847 & 0.794 & 0.682 & 0.689 & 0.771 & & & 0.793 & & 0.752 & 0.629 & 0.560 & 0.618 & & & 0.782 \\
\hline 5 & 0.671 & 0.862 & 0.812 & 0.704 & 0.707 & 0.773 & 0.727 & & 0.7 & & 0.7 & 0.659 & 0.590 & 0.652 & 0.8 & 97 & 0.831 \\
\hline 6 & 0.726 & 0.964 & 930 & 0.812 & 0.812 & 0.861 & 0.793 & & 0.8 & & 0.867 & 0.766 & 689 & 0.764 & & & 0.93 \\
\hline 7 & 0.808 & 1.126 & 1.116 & 0.970 & 0.964 & 1.008 & 0.916 & 0.963 & 0.993 & 0.956 & 1.022 & 0.909 & 0.820 & 0.9 & 1.1 & 37 & 1.024 \\
\hline 8 & 0.866 & 1.275 & 1.303 & 1.131 & & 1.160 & 1.041 & & 1.1 & 1.08 & 1.1 & 1.051 & 0.947 & 1.0 & 1.3 & 51 & 1.107 \\
\hline 9 & 0.882 & 1.334 & 1.390 & 1.207 & & 1.233 & 1.101 & & 1.2 & & 1.2 & 1.1 & 66 & 1.1 & 1.4 & & 1.1 \\
\hline 10 & 0.884 & 1.342 & 1.401 & 1.214 & 201 & 1.237 & 1.101 & 1.171 & 1.203 & 1.151 & 1.256 & 1.121 & 1.011 & 1.124 & 1.4 & 02 & 1.147 \\
\hline 11 & 0.879 & 1.328 & 1.385 & 1.203 & 1.188 & 1.224 & 1.095 & 1.1 & 1.1 & & 1.244 & & & 1.1 & & & 1.141 \\
\hline 12 & 0.851 & 1.252 & 1.280 & 1.113 & & & 1.023 & & & & 1.156 & 1.0 & 0.931 & 1.0 & 1.3 & 1.2 & 1.093 \\
\hline 13 & 0.783 & 1.087 & 1.077 & 0.937 & 0.933 & 0.974 & 0.886 & & 0.9 & 0.9 & 0.9 & 0.8 & 0.7 & 0.8 & 1.1 & 13 & 1.003 \\
\hline 14 & 707 & 0.931 & 0.891 & 0.775 & & & 0.769 & & 0.8 & 0.8 & & 0.7 & & & & & 0.914 \\
\hline 15 & 0.664 & 0.854 & 0.811 & 0.708 & 0.716 & 0.793 & 0.759 & 0.789 & 0.814 & 0.785 & 0.790 & 0.669 & 0.598 & 0.661 & 0.858 & 0.912 & 0.846 \\
\hline 16 & 0.668 & 0.896 & 0.855 & 0.809 & & 0.812 & 0.721 & 0.734 & 0.756 & 0.776 & 0.841 & 0.746 & 0.671 & 0.723 & 0.8 & 0.8 & 0.728 \\
\hline 17 & & 0.827 & 0.670 & 0.632 & & & 0.580 & & & & & & & & & & 0.53 \\
\hline 10 & 0.584 & 0.513 & 0.434 & 0.392 & 0.379 & 0.402 & 0.442 & 0.4 & 0.435 & 0.4 & 0.351 & 0.314 & 0.298 & 0.298 & 0.326 & 0.386 & 0.432 \\
\hline 19 & 0.609 & 0.563 & 0.506 & 0.473 & 0.455 & 0.462 & 0.484 & 0.492 & 0.474 & 0.450 & 0.415 & 0.388 & 0.372 & 0.368 & 0.381 & 0.414 & 0.441 \\
\hline
\end{tabular}

${ }^{a} \mathrm{r}=\mathrm{n}$ denotes the radial region number; $\mathrm{n}$ varies from 1 to 8 for the IFE and from 1 to 9 for the OFE. 


\subsubsection{Coolant void reactivity}

The coolant void reactivity coefficient (CVR) for the coolant in the fuel region was calculated for the BOC and EOC conditions using the MCNP models for these two state points. Two CVR values were calculated for the fuel region for each state point to compare to available measurement data ${ }^{13}$ from HFIR startup tests carried out in the 1960's for the critical configuration identified as HFIRCE-4. In these measurements, done separately for the inner fuel element (IFE) and the outer fuel element (OFE), a few of the fuel plates in a fuel element were replaced with aluminum plates and then the latter replaced with water; the reported void coefficients were estimated by making corrections to measured aluminum coefficients. The calculated CVR data for the LEU and HEU cores are presented in Table 5, along with the reported measurement data. There is a reasonable agreement between the calculated and the measurement data, if considering the differences between the modeled core and the actual experiment configuration and corrections used for the reported experimental data.

Table 5. Coolant void reactivity coefficients (in $(\Delta \mathrm{k} / \mathrm{k}) / \Delta \mathrm{V})$

\begin{tabular}{cccccccc}
\hline \multirow{2}{*}{$\begin{array}{c}\text { Core } \\
\text { state }\end{array}$} & \multirow{2}{*}{ Region } & \multicolumn{2}{c}{ LEU } & \multicolumn{2}{c}{ HEU cycle 400 } & Measurement \\
\cline { 3 - 4 } & & CVR & $\sigma_{\text {CVR }}$ & CVR & $\sigma_{\text {CVR }}$ & CVR \\
\hline BOC & IFE & -0.082 & 0.001 & & -0.102 & 0.001 & -0.080 \\
& OFE & -0.153 & 0.001 & & -0.218 & 0.001 & -0.170 \\
EOC & IFE & -0.064 & 0.001 & & -0.069 & 0.001 & NA \\
& OFE & -0.108 & 0.001 & -0.146 & 0.001 & NA \\
\hline
\end{tabular}

\subsubsection{Flux trap void reactivity}

The variation of $\mathrm{k}_{\mathrm{eff}}$ with the reduction of water density in the flux trap region was calculated for BOC for both LEU and HEU cores and compared to measurement data for the first preconstruction critical experiment (HFIRCE-2) at HFIR that used a prototypic fuel element. The comparison is illustrated in Fig. 1. Experimental data are available for two cases: one case with no target in the flux trap, and one case with a target included. The points shown in Fig. 1 for experimental data were digitized from plots available in ref. 13.

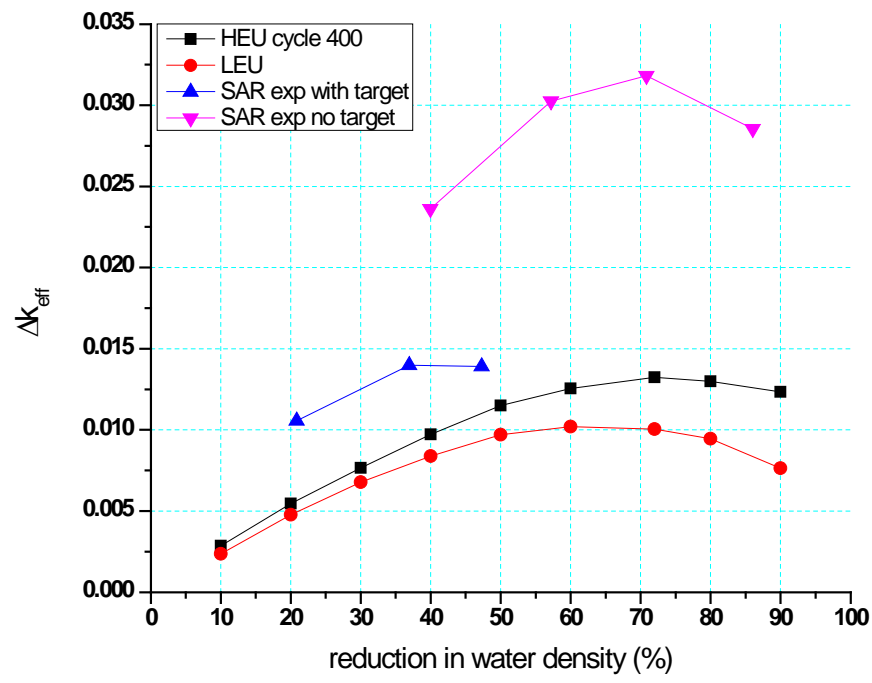

Fig. 1. Variation of $\mathbf{k}_{\mathrm{eff}}$ with the reduction of water density in flux trap region. 
The calculated data for both LEU and HEU cores are less than the $1.5 \% \Delta \mathrm{k} / \mathrm{k}$ value that was adopted in the HFIR SAR ${ }^{4}$ as a design basis reactivity event for protection system design and evaluation. At the time the original SAR measurements and calculations were prepared, the assumed target loading differed from the design present in the computational model. As observed from Fig. 1, the LEU values on the y-axis are always smaller than the corresponding data for the HEU core.

\subsubsection{Effective delayed neutron fraction}

The effective delayed neutron fraction ( $\beta_{\text {eff }}$ ) was calculated using the k-ratio method. ${ }^{2}$ The calculated values for both BOC and EOC states are presented in Table 6. The value currently accepted in the safety basis for HFIR is 0.0076 for both BOC and EOC states.

Table 6. Effective delayed neutron fraction

\begin{tabular}{ccccc}
\hline \multicolumn{2}{c}{ HEU cycle 400 } & & \multicolumn{2}{c}{ LEU } \\
\cline { 1 - 2 } \cline { 4 - 5 } BOC & EOC & & BOC & EOC \\
\hline $0.00736 \pm 0.00011$ & $0.00740 \pm 0.00011$ & & $0.00756 \pm 0.00008$ & $0.00707 \pm 0.00010$ \\
\hline
\end{tabular}

\subsubsection{Isotopic composition in spent fuel}

The isotopic compositions of the spent fuel, the plutonium inventory in particular, are important to safeguards, reactor safety, and waste management. To be loaded to the core, an inner and an outer fuel element in HFIR are required to have the same cycle time and there is no fuel shuffling. After irradiation in the reactor, the fuel is stored in the pool before final disposal. The total mass in the IFE, OFE, and core at EOC for isotopes of the main actinides uranium and plutonium is presented in Table 7. As expected, the production of plutonium increases, given the large fraction of ${ }^{238} \mathrm{U}$ present in the LEU fuel. The total amount of plutonium at EOC is $15 \mathrm{~g}$ for the HEU core and $464 \mathrm{~g}$ for the LEU core.

Table 7. Major actinides inventory (in grams) for HEU and LEU cores at EOC

\begin{tabular}{|c|c|c|c|c|c|c|}
\hline \multirow{2}{*}{ Nuclide } & \multicolumn{3}{|c|}{ HEU cycle 400} & \multicolumn{3}{|c|}{ LEU } \\
\hline & Core & IFE & OFE & Core & IFE & OFE \\
\hline U-234 & 87.55 & 23.29 & 64.26 & 231.68 & 57.22 & 174.46 \\
\hline U-235 & 6596.08 & 1564.79 & 5031.29 & 22048.07 & 5263.72 & 16784.35 \\
\hline U-236 & 534.53 & 185.87 & 348.65 & 786.85 & 253.15 & 533.70 \\
\hline U-238 & 530.49 & 145.60 & 384.90 & 101637.18 & 25642.59 & 75994.59 \\
\hline Pu-238 & 0.34 & 0.15 & 0.19 & 0.37 & 0.15 & 0.22 \\
\hline Pu-239 & 12.04 & 3.44 & 8.60 & 425.22 & 132.65 & 292.57 \\
\hline Pu-240 & 1.60 & 0.58 & 1.02 & 28.48 & 11.37 & 17.11 \\
\hline $\mathrm{Pu}-241$ & 0.73 & 0.29 & 0.44 & 9.43 & 4.33 & 5.10 \\
\hline Pu-242 & 0.07 & 0.04 & 0.03 & 0.37 & 0.22 & 0.15 \\
\hline
\end{tabular}

\subsubsection{Decay heat in spent fuel}

As described in ORNL/TM-2010-318, ${ }^{2}$ a script was developed to extract the depleted fuel composition from the VESTA output files and feed the data into the ORIGEN-ARP depletion and decay analysis sequence in the SCALE code system for source term characterization. Decay calculations were carried out with the ORIGEN-ARP depletion sequence in SCALE to determine the decay heat after shutdown, with the IFE and OFE considered as one source. The total calculated decay heat for the LEU and HEU 
cores is presented in Table 8 and illustrated in Fig. 2 for decay times from shutdown up to 100 years. In addition to the total decay heat value, the component of the decay heat due to the actinides present in the spent fuel is shown. The decay heat due to fission products is the major contributor to the total decay heat for both cores. The total decay heat at three years decay time, which is the decay time after which the fuel elements are considered for shipping from the storage pool to a disposal place, is approximately a thousand times smaller than the total decay heat at the normal discharge time at $1 \mathrm{~d}$ after shutdown. At 10 years decay time, the total decay heat decreases below $100 \mathrm{~W}$ and at 100 years decay time becomes smaller than $10 \mathrm{~W}$.

Table 8. Decay heat for spent fuel-comparison of HEU cycle 400 and LEU cores

\begin{tabular}{|c|c|c|c|c|}
\hline \multirow{3}{*}{$\begin{array}{l}\text { Decay } \\
\text { time }\end{array}$} & \multirow{2}{*}{\multicolumn{2}{|c|}{$\begin{array}{c}\text { Total decay heat } \\
(W)\end{array}$}} & \multirow{2}{*}{\multicolumn{2}{|c|}{$\begin{array}{c}\text { Actinides decay heat } \\
(\mathrm{W})\end{array}$}} \\
\hline & & & & \\
\hline & LEU & HEU & LEU & HEU \\
\hline $0 \mathrm{~s}$ & $9.58 \times 10^{6}$ & $8.02 \times 10^{6}$ & $9.83 \times 10^{4}$ & $4.70 \times 10^{3}$ \\
\hline $10 \mathrm{~s}$ & $5.10 \times 10^{6}$ & $4.27 \times 10^{6}$ & $9.80 \times 10^{4}$ & $4.69 \times 10^{3}$ \\
\hline $10^{2} \mathrm{~s}$ & $2.82 \times 10^{6}$ & $2.33 \times 10^{6}$ & $9.58 \times 10^{4}$ & $4.61 \times 10^{3}$ \\
\hline $10^{3} \mathrm{~s}$ & $1.68 \times 10^{6}$ & $1.37 \times 10^{6}$ & $7.82 \times 10^{4}$ & $3.97 \times 10^{3}$ \\
\hline $10^{4} \mathrm{~s}$ & $7.61 \times 10^{5}$ & $6.14 \times 10^{5}$ & $4.55 \times 10^{4}$ & $2.77 \times 10^{3}$ \\
\hline 1 day & $3.25 \times 10^{5}$ & $2.48 \times 10^{5}$ & $3.48 \times 10^{4}$ & $2.25 \times 10^{3}$ \\
\hline 1 year & $1.59 \times 10^{3}$ & $1.37 \times 10^{3}$ & $1.61 \times 10^{0}$ & $3.44 \times 10^{-1}$ \\
\hline 3 years & $2.83 \times 10^{2}$ & $2.42 \times 10^{2}$ & $1.68 \times 10^{0}$ & $3.45 \times 10^{-1}$ \\
\hline 10 years & $7.82 \times 10^{1}$ & $6.72 \times 10^{1}$ & $1.92 \times 10^{0}$ & $3.50 \times 10^{-1}$ \\
\hline 30 years & $4.79 \times 10^{1}$ & $4.03 \times 10^{1}$ & $2.26 \times 10^{0}$ & $3.41 \times 10^{-1}$ \\
\hline 50 years & $3.07 \times 10^{1}$ & $2.51 \times 10^{1}$ & $2.35 \times 10^{0}$ & $3.18 \times 10^{-1}$ \\
\hline 100 years & $1.10 \times 10^{1}$ & $7.85 \times 10^{0}$ & $2.29 \times 10^{0}$ & $2.57 \times 10^{-1}$ \\
\hline
\end{tabular}

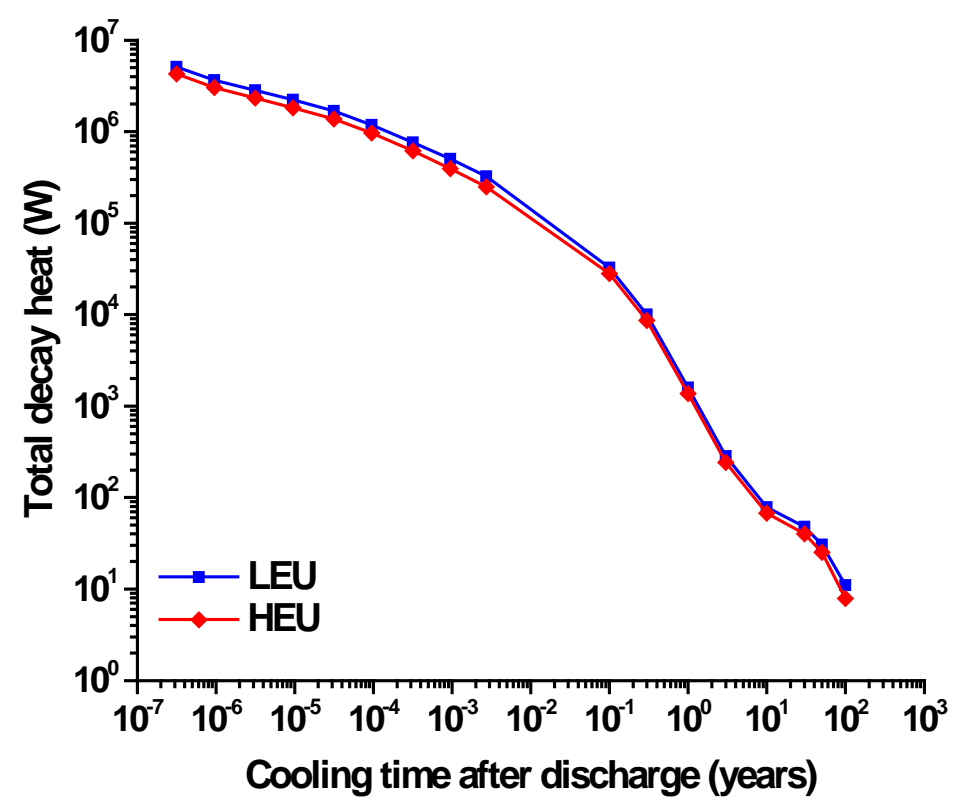

Fig. 2. Decay heat for spent fuel — comparison of HEU cycle 400 and LEU cores. 


\subsubsection{Power distributions for thermal hydraulic analyses}

The COMSOL multiphysics code is being used for complex, three-dimensional thermal hydraulic analyses of the LEU-fueled HFIR core. The LEU fuel plate geometry as modeled in COMSOL consists of coolant channel, aluminum clad, aluminum filler and fuel meat regions; whereas, the MCNP input volumetrically homogenizes these regions. A three-dimensional power density $\left(\mathrm{W} / \mathrm{cm}^{3}\right)$ distribution is required as input to the COMSOL code and, thus, the relative fission densities as calculated in ref. 2 must be converted into power densities for used in the COMSOL simulations. Appendix A describes the methodology that is being implemented to calculate the relative fission densities via MCNP and how these values are converted for use in COMSOL.

\subsubsection{Communication with HFIR Researchers}

Members of the HFIR LEU conversion team met in March 2011 with a good cross-section of researchers who use HFIR's neutron scattering and irradiation capabilities. The purpose of the meeting was for the team to explain the non-proliferation objectives of reactor conversion while ensuring "that the ability of the reactor to perform its scientific mission is not significantly diminished" and "that an LEU fuel alternative is provided that maintains a similar service lifetime for the fuel assembly.” Results of extensive reactor physics analyses were presented by the team to demonstrate that a new, U-Mo monolithic fuel within HFIR's current fuel element geometry can maintain current research performance provided that reactor power is increased from 85 to $100 \mathrm{MW}$ and the fuel region within each plate is contoured axially at the bottom (as well as continuing to be contoured radially.) The team provided some information about HEU/LEU neutron flux in the central target, reflector, and HB-4 regions.

Following the presentation, researchers were asked what additional information they might need to fully understand any impacts of conversion on their work. They were encouraged to identify other locations or information such as gamma heating that would be useful. Several follow-up activities were identified to provide additional information or enable better coupling of core analyses with experimental analyses. No adverse impacts on scattering or irradiation research were identified.

\subsubsection{Path Forward}

Based on the results of the reactor physics analyses performed in FY 2011, the newly developed VESTA depletion models for the HFIR LEU and HEU cores are shown to provide a robust and reliable basis for further HFIR depletion studies and a computational basis for the verification and/or the update of the data included in the HFIR SAR.

The established computational methodology and models will enable inherent future changes, as the proposed manufacturing methodology for the fuel continues to be developed. When available, the actual fuel specifications (e.g., uranium isotopic content, impurities levels) will be included in the models. The impact of these fuel design changes on the core performance remains to be assessed.

To support the development of more advanced, COMSOL-based methods thermal-hydraulics methods for HFIR, a particular effort will be dedicated to enable a seamless integration of spatially-dependent data from neutronics simulations with the COMSOL HFIR model, to efficiently provide performance feedback between neutronics and thermal-hydraulics.

More involved analyses will be needed to provide accurate feedback with respect to the core performance should additional HFIR LEU fuel design options that are more fabrication-friendly be explored, such as optimization of content and spatial distribution for burnable poisons. 


\subsection{THERMAL HYDRAULICS}

\subsubsection{COMSOL}

Thermal-hydraulic analyses of HFIR LEU fuel are described in Preliminary Multiphysics Analyses of HFIR LEU Fuel Conversion using COMSOL. ${ }^{14}$ Additional publications of continuing work are listed as refs. 17-20.

\subsubsection{RELAP5}

\subsubsection{Progress in FY 2011}

The RELAP5 model of HFIR is used to perform transient analyses of postulated accidents for the HFIR Safety Analysis Report (SAR). The RELAP5 model represents the entire HFIR plant including (1) the core and reactor vessel, (2) the primary coolant system, (3) the pressurizer pump and letdown system, (4) the heat exchangers and secondary coolant system, and (5) the control logic for pump operations, valve actuations, and scrams. A point-kinetics model is also included for analyzing reactivity transients. The model was originally developed in the early 1990s using the Mod2.5 version of the RELAP5 code. Documentation for the original model was provided in ORNL/TM-11647 dated February 1993. Significant improvements have been made to the HFIR plant model since 1993, but documentation for these modifications and additions was scattered in numerous RRD calculation reports, and was never combined with the original information in ORNL/TM-11647.

All RELAP5 analyses in the HFIR SAR must eventually be repeated for the new LEU fuel design. The types of RELAP5 analyses described in the current SAR include: (1) increases in heat removal such as reactor trip with failure of post-trip secondary actions, (2) decreases in heat removal such as total loss of secondary cooling, (3) decreases in primary flow such as loss of off-site ac power (LOOP), (4) reactivity transients such as control cylinder ejection, (5) increases in primary coolant inventory such as inadvertent letdown block valve closure, (6) decreases in primary coolant inventory such as a small-break loss-ofcoolant accident (LOCA), and (7) anticipated transients without scram such as pressurizer pump trip.

The RELAP5 effort for the HFIR LEU conversion project during FY 2011 was to incorporate all of the model modifications and additions for HEU fuel that were developed since 1993 into a single input file that can be used to perform all of the SAR transient calculations. While there were previously separate input files for performing simulations with decay heat or reactor kinetics logic, these functions (and many others) have been combined into a single steady-state base model, which is now referred to as the RELAP5 consolidated model of HFIR. Following several preliminary versions, Version 3 of the consolidated model was completed November 2010. This consolidated model represents HEU fuel and continues to be based upon the Mod2.5 version of the RELAP5 code.

The consolidated model is fully documented in ORNL/RRD/INT-154/R0 dated April 2011. This report was created by starting with the previous ORNL/TM-11647 and modifying the manuscript as necessary to describe all of the modifications and improvements that have been added to the model since 1993. The report also includes an appendix containing results for several test calculations that verify the proper operation of version 3 of the consolidated model. In the future, the goal is to revise ORNL/RRD/INT-154 as necessary to keep it consistent with future versions of the model.

As part of preparing ORNL/RRD/INT-154/R0, several minor errors and inconsistencies were discovered in the RELAP5 consolidated model of HFIR. At the end of FY 2011, work is in progress on version 4 of the consolidated model to correct these issues. 
Before converting the consolidated model to represent LEU fuel, the goal is to confirm it can perform all of the transient simulations described in the current SAR for HEU fuel. This additional step is necessary because some of these simulations have not been performed in almost 20 years, and additional model revisions may be necessary to ensure all previous capabilities are fully operational in the consolidated model. The reactivity transient simulations are good examples because they were previously performed in 1993 with a simplified version of the RELAP5 model where only the reactor vessel region was represented with user specified boundary conditions. More powerful workstations are now available that will allow these simulations to be performed with the full-plant model.

During FY 2011, the consolidated model was used to analyze (1) the decrease in heat removal events as described in RRD calculations C-HFIR-2010-038/R0 and C-HFIR-2011-013/R0 and (2) the anticipated transient without scram events as described in RRD calculation C-HFIR-2011-003/R0. Work is in progress at the end of FY 2011 on preliminary pressurizer pump trip, small-break LOCA, and LOOP analyses for HEU fuel operating at $100 \mathrm{MW}$ to quantify thermal margins.

\subsubsection{Plans for FY 2012}

Plans to continue the development and application of the RELAP5 model to support HFIR LEU fuel conversion include:

- complete HFIR model consolidation

- evaluate all SAR Chapter 15 transients for HEU fuel with consolidated model

- interface with COMSOL

\subsection{FISSION PRODUCT RELEASE AND TRANSPORT AND DOSE ANALYSES}

The purpose of this task is to address the HFIR Safety Basis changes associated with the LEU fuel from a fission product release, transport, and offsite consequence point of view. Since the reactor power and fuel type are changing, the fuel properties, the fission product decay heat, and the overall fission product source term will change, thus presenting the potential for a change in offsite consequences in the SAR. The objective of this task is to upgrade the accident analysis tools used in the existing SAR and apply them to the new fuel design and operating envelope to enable preparation of the revised SAR. The revised SAR for the new fuel and operating conditions will then be submitted to DOE for approval.

The existing HFIR SAR is in NRC Regulatory Guide 1.70 format and involves fission product release scenarios in four of the categories of event types considered in SAR Chapter 15, Accident Analysis. The four categories and the bounding dose/consequence cases are presented in Table 9.

Table 9. HFIR accident categories and bounding sequence that involve fuel damage

\begin{tabular}{l|l}
\hline \multicolumn{1}{c|}{ Reg. Guide 1.70 category } & \multicolumn{1}{c}{ Bounding case from HFIR SAR } \\
\hline $\begin{array}{l}\text { Reactivity and power distribution } \\
\text { anomalies }\end{array}$ & Void reactivity insertion into the central target region \\
\hline $\begin{array}{l}\text { Decrease in reactor coolant system flow } \\
\text { rate }\end{array}$ & Blockage of fuel element coolant channels \\
\hline $\begin{array}{l}\text { Decrease in reactor primary coolant } \\
\text { inventory }\end{array}$ & Large break LOCA into the reactor pool \\
\hline $\begin{array}{l}\text { Radioactive releases from a subsystem or } \\
\text { component }\end{array}$ & Damage to stored spent fuel-dropped reactor pool dam \\
\hline
\end{tabular}


No work was performed during this year on the reactivity insertion accident category shown in Table 9, except to highlight (via presentations at U. S. High Power Research Reactor [USHPRR] meetings) the need for input on LEU fuel performance limit data or modeling sufficient to characterize the upper bound of rapid energy addition that the new LEU fuel can tolerate without failure. This limit is usually expressed in cal/g of fuel and is translated into an integrated power (MW-s) limit for application to Chapter 15 reactivity calculations.

Work performed this year for the flow blockage accident category is discussed in Section 2.4, below.

For the large break LOCA and damaged spent fuel accidents in Table 1, the HFIR SAR assumes the fission products are released locally at the point of fuel damage and models the transport of the fission products through the building to produce a source term for environmental release. The MELCOR code was used to model the HFIR primary coolant system, pool systems, and confinement to calculate the transport of released fission products to the assumed environmental release points. The ORNL-developed TRENDS code was used in concert with the MELCOR model to calculate iodine, cesium, and tellurium chemistry in the primary and pool systems. These codes must be updated before application to the new LEU source term.

During this year, the MELCOR version 1.8.6 executable was obtained from Sandia National Laboratories, and sample calculations were executed with a desk-top computer. Selected MELCOR 1.8.6 documentation was reviewed to develop sufficient expertise to reconstitute the HFIR MELCOR models. A previous HFIR MELCOR 1.8.1 calculation ${ }^{15}$ was obtained and output from that calculation was employed as an aid to reestablish the HFIR input necessary to model the fission product transport through the HFIR reactor coolant system and confinement. As a first case, attention was focused on a loss of coolant accident occurring in the heat exchanger cell. Work is planned to continue in FY 2012 on the MELCOR modeling.

For offsite dose/consequence analysis, the existing SAR uses a subcontractor-developed NRC Regulatory Guide 1.4 spreadsheet to calculate total effective dose equivalent (TEDE) dose at the site boundary and offsite receptors. Originally, onsite dose calculations were performed by subcontractors with a version of the CRACEZ code and subcontractor-developed models for local building wind field effects. For the updated dose/consequence calculations to support the LEU conversion, it was decided to convert the dose calculation modeling methodology to use of the DOE-Toolbox code MACCS for site boundary and offsite receptor locations. No decision has been made on the updated methodology for onsite dose/consequence modeling.

During this year the only work performed to support the MACCS modeling effort was to collaborate with ORNL-site experts on dose/consequence modeling and identify resources for update of the site-specific meteorology calculations. For the onsite calculations, the ARCON96 code was considered for use as a replacement of the old CRACEZ code, but no final decisions were made regarding this analysis tool. Work is planned to continue in FY 12 on the dose/consequence modeling.

\subsection{FLOW BLOCKAGE ACCIDENT ANALYSES}

The decrease in reactor coolant system flow rate category in Table 9 involves a coolant flow blockage of the fuel at full reactor power as the bounding limiting event. This scenario involves a rapid fuel plate heat-up, melt, and potential melt-water interaction capable of producing steam explosions that could challenge the reactor pressure vessel. The objective of this task is to reconstitute the modeling of the flow blockage event that was done for the HEU fuel and then reevaluate the energy source term and fluid structure interactions that could occur within the HFIR vessel for the new LEU fuel. 
In Section 15.3.3 of the existing HFIR SAR, the approach to flow blockage analysis involves beginning with an estimate of $24 \%$ of the core as the amount of fuel that could be melted and available for interaction with the water mass at the outlet of the core. The $24 \%$ is based on estimates in the original accident analysis for the HFIR, supported by hand calculations and modeling of the core using the RELAP5 code. For the existing SAR, interactions between the molten fuel and water were modeled using an energetics code named FCIMOD, which modeled the melt-water interactions and produced a pressure pulse history for evaluation by the fluid-structure interaction models.

The FCIMOD code is no longer supported and has subsequently been replaced by the TEXAS-V code. The major improvements in this code are the addition of fragmentation models which lead to a better mechanistic description of the melt-water interaction than was included in FCIMOD. Previous work with FCIMOD required an estimate of the fuel to coolant mass ratio available for interaction. The TEXAS-V code calculates the melt breakup and fragmentation process of the fuel, thus eliminating the need for estimates.

Work performed this year involved reviewing the existing modeling in Section 15.3.3 of the SAR, obtaining the TEXAS-V code, and installing and running preliminary models of the HFIR melt-water interaction model of the flow blockage. Work will continue into FY 2012 in this area.

\subsection{OREGON STATE UNIVERSITY (OSU) HYDRAULIC TESTING}

Proposed testing to support the design and safety analysis efforts for conversion of the HFIR to U-Mo based fuel involves hydraulic tests to be performed at the OSU Hydro Mechanical Fuel Test Facility (HMFTF). The purpose of the HFIR tests is to verify the hydraulic similitude of U-Mo foil-core plates to the $\mathrm{AL}-\mathrm{U}_{3} \mathrm{O}_{8}$ dispersion-core plates. These tests are envisioned as comparison experiments to gather flow, pressure drop, coolant velocity, plate deflection, and plate vibration information to verify that the new plate design performs favorably in comparison to the old plate design. In addition, the hydraulic experiments are expected to gather detailed fuel performance data that can be used to benchmark the new computational fluid dynamics and structural mechanics multiphysics models that are being developed for the updated HFIR thermal/hydraulics analysis.

The proposed HMFTF testing to support HFIR involves isothermal testing of single plate and multi-plate assemblies. The single plate tests are intended to establish contrast between the flat plate geometry and involute plate geometry and the multi-plate tests are intended to provide benchmarking data to support multiphysics code calculations of the overall velocity and pressure distribution of a fuel element assembly. The multi-plate tests are also envisioned to provide benchmark data for narrow-wide channel code calculations. Table 10 describes the series of tests that are desired. 
Table 10. HFIR-Specific tests desired for HMFTF

\begin{tabular}{|c|c|c|c|c|c|c|}
\hline $\begin{array}{l}\text { Series } \\
\text { No. }\end{array}$ & Description & $\begin{array}{l}\text { HFIR hydraulic } \\
\text { segment type }\end{array}$ & $\begin{array}{c}\text { All } \\
\text { aluminum } \\
\text { plates }\end{array}$ & $\begin{array}{c}\text { Depleted U } \\
\text { dispersion } \\
\text { plates }\end{array}$ & $\begin{array}{c}\text { Depleted } \\
\text { U-Mo foil- } \\
\text { plates }\end{array}$ & $\begin{array}{l}\text { Channel flow: } \\
\text { Full-full power } \\
\text { steady state } \\
\text { design flow }\end{array}$ \\
\hline 1 & $\begin{array}{l}\text { Single plate-2 } \\
\text { channels }\end{array}$ & $\begin{array}{l}\text { Flat plate-data } \\
\text { could be provided } \\
\text { by generic test } \\
\text { assembly. }\end{array}$ & $\mathbf{X}$ & & $\mathbf{X}$ & Full \\
\hline 2 & $\begin{array}{l}\text { Single plate-2 } \\
\text { channels }\end{array}$ & Involute plate & $\mathbf{X}$ & $\mathbf{X}$ & $\mathbf{X}$ & Full \\
\hline 3 & $\begin{array}{l}\text { Multiple } \\
\text { involute-9 plates }\end{array}$ & $\begin{array}{l}\text { Involute plate: } \\
9 \text { plate pack with } \\
8 \text { normal channels }\end{array}$ & $\mathbf{X}$ & & $\mathbf{X}$ & Full \\
\hline 4 & $\begin{array}{l}\text { Multiple } \\
\text { involute-9 plates }\end{array}$ & $\begin{array}{l}\text { Involute plate: } \\
9 \text { plate pack with } \\
7 \text { normal channels } \\
\text { and one wide } \\
\text { channel }\end{array}$ & $\mathbf{X}$ & & $\mathbf{X}$ & Full \\
\hline
\end{tabular}

The operating conditions envisioned for the testing are provided in Table 11 . Tables 10 and 11 were presented to OSU HMFTF and generic test plate assembly design personnel at the January, $2011 \mathrm{U}$. S. HPRR meeting.

Table 11. Operating conditions for HFIR LEU testing

\begin{tabular}{l|c|c|c|c|c}
\hline \multicolumn{1}{c|}{ Variable } & Min., TSR & Max., TSR & $\begin{array}{c}\text { Nominal full } \\
\text { power }\end{array}$ & $\begin{array}{c}\text { Nominal } \\
\text { ahutdown }\end{array}$ & Testing \\
\hline Pressure, psia & 325 (fuel inlet) & $\begin{array}{c}650 \\
\text { (reliefs) }\end{array}$ & 475 (fuel inlet) & $\begin{array}{c}475 \text {-down to- 10 } \\
\text { (fuel inlet) }\end{array}$ & $\begin{array}{c}475 \text {-down to- } 10 \\
\text { (fuel inlet) }\end{array}$ \\
\hline Temperature, F & 90 (vessel) & $\begin{array}{c}140 \text { (opr.) } \\
200(\text { dsgn.) }\end{array}$ & 120 & 120 & $90-200$ \\
\hline $\begin{array}{l}\text { Flow-whole } \\
\text { core, gpm }\end{array}$ & $\begin{array}{c}1100 \text { (opr.) } 750 \\
\text { (shutdown) }\end{array}$ & 14200 & 13000 & 2072 & $750-14200$ \\
\hline $\begin{array}{l}\text { Inner element } \\
\text { flow (total/per } \\
\text { channel), gpm }\end{array}$ & $\begin{array}{c}\text { (396/2.3)- } \\
\text { operating } \\
(270 / 1.6)- \\
\text { shutdown }\end{array}$ & $5112 / 29.9$ & $4680 / 27.4$ & $746 / 4.4$ & $270 / 1.6-$ \\
\hline $\begin{array}{l}\text { Outer element } \\
\text { flow (total/per } \\
\text { channel), gpm }\end{array}$ & $\begin{array}{c}\text { (704/1.9)- } \\
\text { operating } \\
(480 / 1.3)- \\
\text { shutdown }\end{array}$ & $9088 / 24.6$ & $8320 / 22.5$ & $1326 / 3.6$ & $5112 / 29.9$ \\
\hline
\end{tabular}




\subsection{INVOLUTE PLATE THERMAL DEFLECTION SEPARATE EFFECTS TESTING}

The HFIR fuel design involves a combination of large coolant velocities, thin Al plates, and a large power density. Each fuel plate is constrained by a weld between the plate edges and the fuel element sideplates at each inch along the fuel axial length. When the reactor is operating at steady state, thermally-induced stresses exist between the cold sideplates and the hot fuel core which cause plate deflections that may affect the coolant channel dimensions and provide adverse feedback to the fuel average and hot spot temperatures. This aspect of the HFIR fuel thermal/hydraulic response was addressed in the original HFIR design by experiments performed by Cheverton and Kelly that produced correlations for the involute plate deflections that were then hard-wired into the thermal/hydraulic design and safety analysis code. The Cheverton-Kelly tests also included verification of the analytical model for plate deflection as a result of pressure difference across the plate, plus measurements of creep performance and thermal cycling performance of the plates to show that these areas were not significant concerns for the design.

Since the new LEU fuel plate design may involve deflections that could be different than the $\mathrm{U}_{3} \mathrm{O}_{8}$ dispersion-core plates, and the interactions of the new plates at the sideplate welds may be significantly different, it is important to benchmark the multiphysics code calculations to the original tests that were done for the HFIR plates and then apply the benchmarked codes to the U-Mo foil plate design. COMSOL analysis of the Cheverton-Kelly test information during FY 2011 has been encouraging and at this point it appears as if complete replication of the old tests may not be necessary. Critical evaluation of the COMSOL validation efforts against the Cheverton-Kelly testing will be performed during FY 2012 and a final decision will be made regarding the necessity of separate effects thermal-structural testing of the LEU plates.

Figure 3 shows photographs of the Cheverton-Kelly experimental apparatus, which consisted of a single fuel plate mounted on a carriage and instrumented with high temperature position sensors across the span of the fuel plate. The apparatus was inserted into an oven and the differential thermal expansion between the aluminum plate and the steel plate base subassembly is used to mimic the differential thermal expansion between the hot fuel plate and the cold sideplate of the reactor. The ORNL Research Reactors Division retains original design drawings of the apparatus and subassembly parts so that if thermalstructural interaction testing becomes necessary, the apparatus can be rebuilt and used to validate COMSOL calculations for the U-Mo plates. 

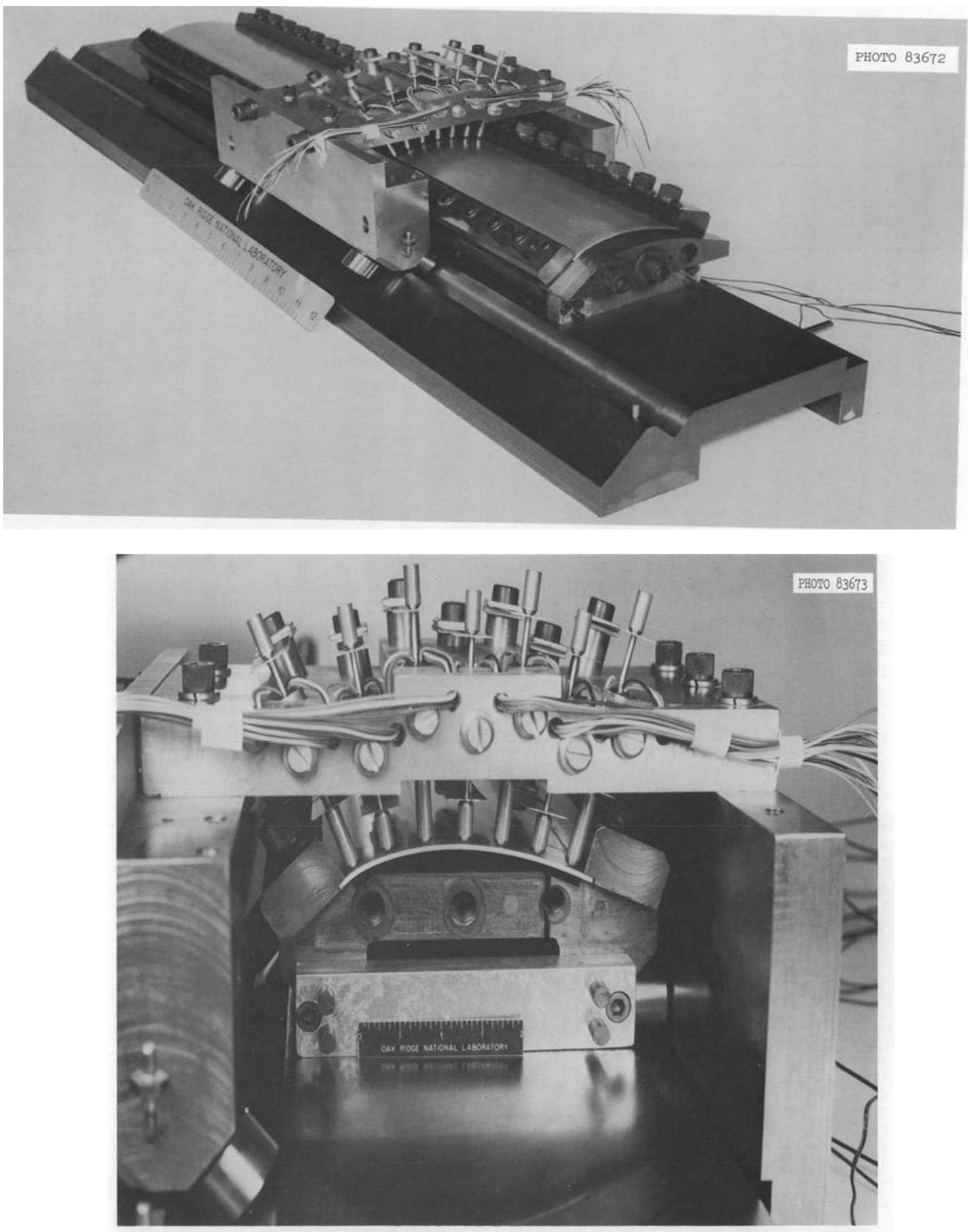

Fig. 3. Photographs of Cheverton-Kelly test apparatus — side and end views. 


\subsection{HFIR LEU FUEL CONVERSION SCHEDULE}

\subsubsection{Progress During FY 2011}

During FY 2011, the HFIR LEU conversion schedule documented in ref. 16 was revised extensively based on a more current understanding of the GTRI/RERTR conversion program and the impacts of conversion on the HFIR plant and infrastructure. Activities were added and deleted in support of a fivephase conversion strategy that includes:

1. Demonstrate HFIR operation for one cycle at $100 \mathrm{MW}$ with an HEU core of the current design in order to complete secondary side modifications for increased heat removal.

2. Conduct zero-power criticality testing of the lead test core in the proposed HFIR pool critical facility.

3. Conduct low-power testing of the lead test core in the HFIR vessel.

4. $\quad$ Conduct full-power testing of the lead test core for one cycle.

5. Complete conversion for operation of HFIR at $100 \mathrm{MW}$ with production LEU cores.

Activities were logically sequenced and all predecessor and successor relationships were established. Activity durations were intuitively estimated and have not yet been effort- or resource-loaded. Emphasis was placed on identifying all of the interfacing links with the overall GTRI USHPRR conversion program schedule so that they could be used in concert to manage HFIR conversion activities and establish funding and staffing requirements. Those interfacing links are provided in Table 12 . The dates were projected by ORNL staff based on the latest available GTRI conversion program schedule (data date of November 5, 2010.) The revised HFIR conversion schedule was provided to the GTRI program on September 30, 2011.

Table 12. Proposed interfacing links between HFIR LEU conversion schedule 09/30/2011)and GTRI conversion program

\begin{tabular}{l|c}
\multicolumn{1}{c}{ Activity } & $\begin{array}{c}\text { Projected } \\
\text { completion } \\
\text { date }\end{array}$ \\
\hline ORNL specifies to FD HFIR fuel properties data needed & $12 / 23 / 11$ \\
\hline FD issues Fuel Properties Handbook & $11 / 26 / 12$ \\
\hline $\begin{array}{l}\text { FFC completes base fuel fabrication process } \\
\text { development }\end{array}$ & $1 / 1 / 13$ \\
\hline $\begin{array}{l}\text { ORNL works with other USHPRRs and FFC to develop } \\
\text { base fuel spec and fabrication process spec requirements }\end{array}$ & $3 / 26 / 13$ \\
\hline $\begin{array}{l}\text { FFC completes complex fuel fabrication process } \\
\text { development }\end{array}$ & $7 / 1 / 13$ \\
\hline $\begin{array}{l}\text { ORNL specifies to FFC requirements (technical and } \\
\text { QA) for HFIR fuel and fabrication process specs }\end{array}$ & $7 / 29 / 13$ \\
\hline $\begin{array}{l}\text { FFC prepares draft HFIR fuel and fabrication process } \\
\text { specs }\end{array}$ & $9 / 23 / 13$ \\
\hline $\begin{array}{l}\text { ORNL reviews and approves HFIR fuel and fabrication } \\
\text { process specs }\end{array}$ & $10 / 21 / 13$ \\
\hline FFC issues HFIR fuel and fabrication process specs & $10 / 22 / 13$ \\
\hline $\begin{array}{l}\text { B\&W NOG submits to ORNL preliminary HFIR lead } \\
\text { test core certification package }\end{array}$ & $1 / 1 / 15$ \\
\hline $\begin{array}{l}\text { B\&W NOG delivers to ORNL HFIR lead test core with } \\
\text { certification package }\end{array}$ & $3 / 17 / 17$ \\
\hline FFC issues As-Fabricated Fuel Properties Report & $4 / 9 / 14$ \\
\hline $\begin{array}{l}\text { ORNL makes recommendations to FD for base fuel } \\
\text { irradiation test plan }\end{array}$ & $3 / 2 / 12$ \\
\hline
\end{tabular}


Table 12 (continued)

\begin{tabular}{l|c}
\hline FD completes base fuel irradiation testing & $2 / 1 / 13$ \\
\hline $\begin{array}{l}\text { ORNL specifies requirements to FD for HFIR fuel } \\
\text { irradiation test plan }\end{array}$ & $5 / 25 / 12$ \\
\hline FD issues Base Fuel Qualification Report & $7 / 22 / 13$ \\
\hline FD issues Complex Fuel Qualification Report & $6 / 23 / 14$ \\
\hline ORNL provides input to OSU generic hydraulic test plan & $12 / 23 / 11$ \\
\hline FD-OSU issues Generic Hydraulic Test Report & $10 / 28 / 13$ \\
\hline ORNL provides input to OSU HFIR hydraulic test plan & $4 / 14 / 14$ \\
\hline FD-OSU issues HFIR Hydraulic Test Report & $3 / 17 / 15$ \\
\hline $\begin{array}{l}\text { B\&W NOG delivers to ORNL HFIR LEU core with } \\
\text { certification package }\end{array}$ & $11 / 1 / 19$ \\
\hline
\end{tabular}

Noteworthy items recognized during the revision of the HFIR conversion schedule included:

1. The five phases of the HFIR conversion strategy fit together nicely and allow the safety basis revisions and regulatory approvals to proceed step-wise and confidence in reliable LEU fuel performance to grow while other program fuel development and fuel fabrication activities progress.

2. The DOE regulatory interfacing activities that were deferred from FY 2011 due to budget reductions are close to becoming critical path items. These include declaring that HFIR LEU fuel conversion is a major modification, establishing a joint DOE-contractor Integrated Project Team and a contractor Safety Design Integration Team for HFIR conversion, and issuing a Safety Design Strategy and a Safety Design Report.

3. The duration between the completion of the lead test core testing and the projected conversion startup after delivery of the first set of production LEU cores (approximately 20 months) is not adequate to allow enough cooling for transportation of the lead test core in order to perform a thorough post-irradiation examination to inform production, safety analyses, or regulatory approvals.

\subsubsection{Plans for FY 2012}

The revised HFIR LEU fuel conversion schedule will be integrated with the current overall GTRI program schedule to ensure that all interfacing links are included and that dates match. The level of detail will be expanded and the schedule will be effort-, resource-, and cost-loaded.

\subsection{SAFEGUARDS AND SECURITY}

\subsubsection{Total Gamma Source}

As described in ORNL/TM-2010/318, the dose rates for LEU spent fuel were calculated and presented in comparison with HEU spent fuel. 


\subsubsection{Safeguards Category for LEU Fuel}

As described in ORNL-TM-2010/318, nuclear materials are controlled and accounted for on the basis of the classification dividing such materials into categories according to their strategic or financial importance and their potential environmental threat. Fresh LEU fuel would be attractiveness level E, category IV. Spent LEU fuel elements would be attractiveness level D, category IV, which is the same as for spent HEU fuel assemblies.

The strategic significance of nuclear material is distinguished from the attractiveness level. Fresh LEU fuel would be classified as "material of moderate strategic significance." This classification is "less" than for the current HEU fuel elements which, if inner and outer elements are taken together, would be strategic special nuclear material. 



\section{FUEL FABRICATION CAPABILITY (FFC)}

\subsection{REFERENCE FLOW SHEETS}

This activity has been to provide advice to the FFC program manager. In previous years, drafts of detail "reference" flow sheets of all manufacturing processes have been developed with input from various program participants including Babcock \&Wilcox/Y-12 (Y-12), Idaho National Laboratory (INL), Los Alamos National Laboratory (LANL), and Babcock \&Wilcox Company Nuclear Operating Group (B\&W NOG). During this year, these detail flow sheets have undergone minor revisions and the interface point between the head end processes and the fuel fabricator (B\&W NOG) for the fuel plate fabrication was redefined. The head end at Y-12 is now responsible only for providing a single size LEU/Mo coupon ( 6” x 6” x 1/8”) without the zirconium diffusion barrier. (In the near term, Y-12 will continue to supply Zr-clad foils to Lynchburg for the fuel development irradiation test program.) For the FFC program, the application of the zirconium diffusion barrier and the rolling of the U/Mo foils to finished thicknesses and dimensions will be accomplished by the fabricator at B\&W NOG. Summaries of the most recent flow sheets for the head end (Y-12) processes are depicted in Fig. 4 and for fabricating the flat fuel plates (B\&W NOG) in Fig. 5. The fabrication processes for curved plates and fuel elements as previously presented have not changed. Currently, the head end processes at Y-12 are undergoing some modification due to issues encountered in rolling full length foils for irradiation tests.

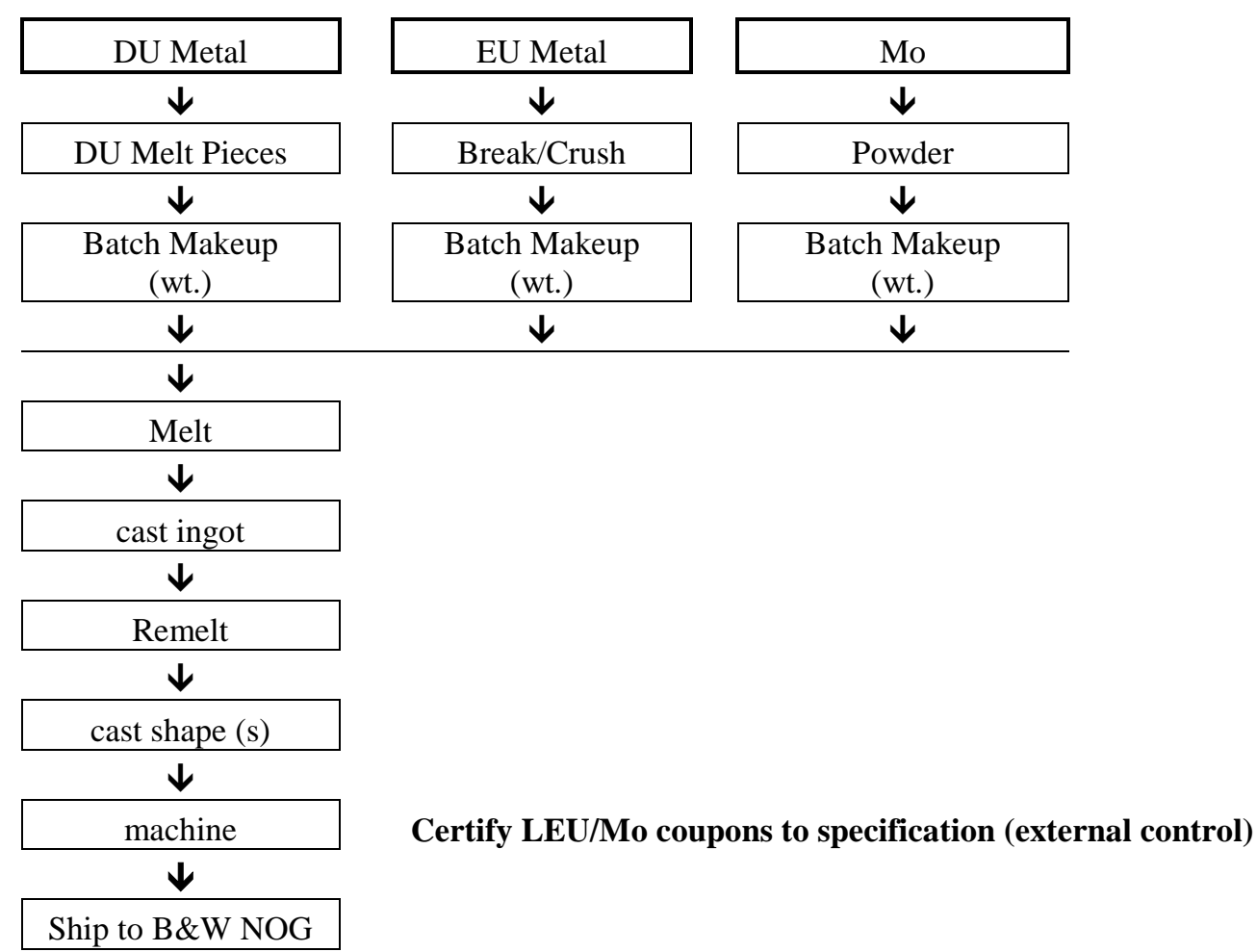

Fig. 4. Head end processes for LEU/Mo coupon (Y-12). 
LEU-Mo Zr Clad Sheets

\begin{tabular}{|c|}
\hline LEU Foil Coupons \\
$\downarrow$ \\
$\downarrow$ \\
\hline Assemble Can \\
$\downarrow$ \\
\hline Weld Can \\
$\downarrow$ \\
\hline Hot Roll \\
\hline$\downarrow$ \\
\hline Remove Can \\
\hline$\downarrow$ \\
\hline Cold Roll \\
\hline$\downarrow$ \\
\hline Trim Edges/Ends \\
\hline$\downarrow$ \\
\hline Identification \\
$\downarrow$ \\
\hline Production Staging \\
\hline \\
\hline Trim Edges/Ends \\
\hline$\downarrow$ \\
\hline Foils for HPRR \\
\hline \\
\hline LEU/Mo Sheets \\
\hline$\downarrow$ \\
\hline Slit into strips \\
\hline \\
\hline Cold Roll \\
\hline$\downarrow$ \\
\hline
\end{tabular}

Certified LEU foils to specification (47 types) internal process controlled

CLAD FOILS

Certified LEU flat foils to specification (47 types)

External process controlled

LEU AL CLAD FLAT FUEL PLATES

\begin{tabular}{l}
\hline Finished Foils \\
$\downarrow$ \\
$\downarrow$ \\
\hline Clean \\
$\downarrow$ \\
\hline HIP Assembly \\
$\downarrow$ \\
\hline Load HIP Can \\
$\downarrow$ \\
\hline HIP \\
$\qquad$ \\
\hline Disassemble HIP Can \\
$\downarrow$ \\
\hline UT Inspect \\
$\downarrow$ \\
\hline Machine thickness - trim \\
$\downarrow$ \\
\hline UT Inspect \\
$\downarrow$ \\
\hline Flat Plates \\
\hline
\end{tabular}

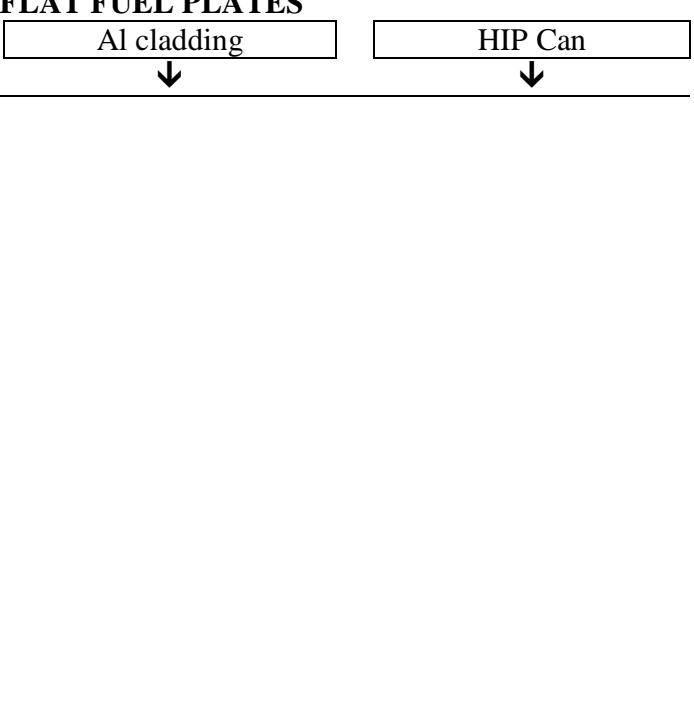

Certified Zr clad LEU flat plates to specification (47 types) External process controlled

Fig. 5. Flat plate fabrication processes (B\&W NOG LEU/Mo Zr clad sheets). 


\subsection{OUTLINE OF COUPON SPECIFICATIONS}

The majority of the work this year has been in accessing the head end processes and developing outlines for intermediate product specifications for coupons and fuel foils applicable to FFC. The successful manufacture of any UMo foil fuel will be totally dependent on the quality of the coupons. The properties of each foil will be largely established in each specific cast coupon because many of its attributes important to the function of the individual plate(s) can only be measured and verified at this stage in manufacturing. Traceability of each individual cast coupon will also be required for quality assurance purpose (i.e., NQA-1). Therefore, the coupon specification(s) must be an integral part of the fuel element specification for each reactor and must be approved by those reactor operators. In addition, the fabricator also needs to approve the coupon specification as some of the identified chemical attributes (e.g., carbon inclusions and gross carbon level) and essentially all of the identified physical attributes will affect the subsequent manufacturing processes and production yields.

The sampling for chemical attributes and the statistics for acceptance of coupons (discrete components) based on this sampling will be significantly different than has been used for the acceptance of $\mathrm{U}$-containing particles (i.e., $\mathrm{U}_{3} \mathrm{O}_{8}$ ) or $\mathrm{U}$ metal supplied for manufacturing fuel particles for use in a dispersion fuel. The metal supplied for dispersion fuel is homogenized in the subsequent melting and particle preparation steps. For particulate fuels, the sampling statistics of particles are well established and fuel particles from a single qualified/certified lot can be used in manufacturing many fuel plates using this statistical understanding.

Many of the chemical/trace element requirements for coupons are comparable to fuel particles (and $\mathrm{U}$ metal supplied to manufacture fuel particles (i.e., UAlx)). However, some chemical attributes including carbon inclusions and U-235 distribution and most physical attributes are not applicable to particulate fuels. Outlines of the key attributes for the process, as well as chemical and physical specification requirements for U/Mo coupons, are listed in Tables 13 and 14.

Table 13. Outline of process specification requirements for UMo coupons

\begin{tabular}{c|l}
\hline \multicolumn{1}{c|}{ Parameter } & \multicolumn{1}{c}{ Comments } \\
\hline Process Qualifications & Multiple lots compliance with target specification \\
\hline Coupon Engineering Drawings & Required part of specification approved by buyer(s) \\
\hline Establish Quality Assurance Plan & QA plan approved by buyer(s) \\
\hline Process Flow sheet & Outline flow sheet approved by buyer(s) \\
\hline Establish sample plan for qualification & \\
\hline Process Capabilities & Determine statistical process capabilities \\
\hline Operator qualification & Part of QA plan \\
\hline Key process parameters & \\
\hline batch makeup/run sheets & Input data on batch makeup; lot identification of raw materials \\
\hline melt furnace time/temperatures & Time/temperature requirements \\
\hline furnace atmosphere during melt & Time/pressure requirements \\
\hline casting mold setup/casting run sheets & \\
\hline casting(s) cropping/machining run sheets & \\
\hline
\end{tabular}


Table 14. Outline of chemical and physical specifications for U/Mo coupons

\begin{tabular}{|c|c|c|c|c|c|}
\hline Sampling & Establish sampling plan & Inspection & Analysis & $\begin{array}{c}\text { Nominal } \\
\text { values }\end{array}$ & $\begin{array}{l}\text { Tol. } \\
(+/-)\end{array}$ \\
\hline & Chemical requirements & & & & \\
\hline & Physical requirements & & & & \\
\hline \multirow{15}{*}{ Chemical } & U in U-Mo Alloy (\%) & Sample & $\mathrm{ICP}^{1}$ & $90 \%$ & 1 \\
\hline & Mo in U-Mo Alloy (\%) & Sample & ICP & $10 \%$ & 1 \\
\hline & Mo isotopic composition & & & & \\
\hline & U-235 Enrichment (\%) & Sample & $\begin{array}{l}\text { Isotopic } \\
\text { dilution }\end{array}$ & $19.75 \%$ & 0.25 \\
\hline & Other U isotopes & Sample & $\begin{array}{l}\text { Isotopic } \\
\text { dilution }\end{array}$ & & \\
\hline & Trans U (alpha) & Sample & & $<600 \mathrm{~Bq} / \mathrm{g}$ & \\
\hline & Calcium & Sample & ICP & $<100 \mathrm{ppm}$ & \\
\hline & Carbon & Sample & Leco $^{2}$ & $<350 \mathrm{ppm}$ & \\
\hline & Carbon inclusions & Sample & Section & $>1 / 32$-in. diam & \\
\hline & $\mathrm{Br}, \mathrm{Cl}, \mathrm{F}, \mathrm{I}$ & Sample & Uanions/ ICP & $<20 \mathrm{ppm}$ & 10 \\
\hline & Sodium & Sample & ICP & $<25 \mathrm{ppm}$ & \\
\hline & Other trace elements & Sample & ICP & Typical panel & \\
\hline & EBC & Calculation & & $<3 \mathrm{ppm}$ & \\
\hline & Contained gas content & Sample & Leco & $<$ TBDcc/g & \\
\hline & Immersion density & Sample & Porosimetry & $17.2 \mathrm{~g} / \mathrm{cc}$ & 0.2 \\
\hline \multirow[t]{23}{*}{ Physical } & Thickness (in.) & $100 \%$ & Micrometer & $0.100-0.200$ in. & 0.005 \\
\hline & Width (in.) & $100 \%$ & Micrometer & $1->4$ in. & 0.005 \\
\hline & Length (in) & $100 \%$ & Micrometer & $2->6$ in. & 0.005 \\
\hline & Weight (g) & $100 \%$ & Balance & $1,268 \mathrm{~g}$ & $1 \%$ \\
\hline & Density (g/cc) & $100 \%$ & Calculation & $17.2 \mathrm{~g} / \mathrm{cc}$ & 0.2 \\
\hline & Surface finish & $100 \%$ & Visual & $<64 \mathrm{rms}$ & \\
\hline & Surface defects & $100 \%$ & & & \\
\hline & pits( bottom obvious), & & $\begin{array}{c}\text { Depth } \\
\text { micrometer }\end{array}$ & $<1 / 32$-in. deep & 0.005 \\
\hline & voids ( bottom not obvious), & & Optical & $<1 / 32$-in. diam. & 0.005 \\
\hline & $\begin{array}{l}\text { scratches (> .003-in. wide; } \\
>1 / 4 \text {-inch long) }\end{array}$ & & Optical & $<0.003$-in. deep & 0.001 \\
\hline & Inclusions & & Optical & $<1 / 8$ in. diam & 0.005 \\
\hline & Edge contour & $100 \%$ & Visual & & \\
\hline & Edge defects (cracks) & $100 \%$ & Visual & & None \\
\hline & Surface cleanliness & $100 \%$ & Visual & & \\
\hline & Homogeneity - & $100 \%$ & X-ray & & \\
\hline & ${ }^{235} \mathrm{U}$ distribution & $100 \%$ & Gamma scan & & \\
\hline & Spot defects & & & $<1 / 8$-in. diam & \\
\hline & Microstructure - destructive exam & Sample & Sections & & \\
\hline & Grain size and microstructure & Sample & & & \\
\hline & Inclusions & Sample & & $<1 / 8$-in. diam & \\
\hline & Mo in U-Mo Alloy (\%) & Sample & & $10 \%$ & $<2 \%$ \\
\hline & Phase identification & Sample & & $<\mathrm{TBD} \% \alpha$ & \\
\hline & Packaging and shipping & & & & \\
\hline
\end{tabular}

${ }^{1}$ ICP-MS — inductively coupled plasma mass spectroscopy.

${ }^{2}$ LECO — glow discharge spectroscopy. 
Table14 contains a preliminary list of chemical and physical attributes that need to be characterized and included in a coupon specification. Other attributes may need to be added. The analysis methods listed were mainly derived from existing specifications for particles and need to be better defined. For the inspection of the physical attributes, depending on the maximum permissible defect level in coupon specification, some redundant inspections may be required. This is because the $100 \%$ inspection level may not be $100 \%$ effective in identifying all the defects present (e.g., a single $100 \%$ visual inspection by an inspector is only $80 \%$ effective).

Multiple coupons and metal casting lots representative of the production product should be used to determine the statistical process capabilities and the normal range of variations attainable with the process. For the attributes that must be determined from samples, a statistically based sampling plan will be required. This sampling plan should be based on data from coupons representative of the production products. The importance of the identified attributes to fuel fabrication and irradiation performance needs to be determined and the specific quality assurance requirements (e.g., 3 sigma) for controlling the identified key attributes needs to be established.

\subsection{HEAD END PROCESSES}

Recent quality issues at Y-12 in the fabrication of Mo foils for the base fuel irradiation testing program with ATR size foil samples will most likely result in some changes in Y-12's "baseline” intermediate scale head end processes for UMo coupons. Homogenously incorporating the high melting point Mo $\left(>2600^{\circ} \mathrm{C}\right.$ ) with uranium has been an issue with the Y-12 "baseline" vacuum induction melt (VIM) process in achieving a homogeneous U/Mo alloy with low carbon and inclusions. These changes may include the preparation of a master alloy by a vacuum arc remelt (VAR) process.

In considering the head end processes for FFC full-scale production, the preparation of a master alloy is a consideration based on the recommendation of uranium metal processing experts from Y-12, LANL, and ORNL/Manufacturing Sciences Corporation (MSC). The recommendation of these experts is to prepare a depleted (or natural) uranium (DU) master alloy (DU-14.5\% Mo) first and then use this master alloy in making the LEU/Mo alloy. The selection of natural or depleted uranium as the starting material would be based on the availability of large quantities of uranium with suitable purity levels (i.e., low carbon). With a master alloy, relatively small melt pieces (1/2 in. $\mathrm{x} 2 \mathrm{in.} \times \mathrm{in}$.) would be produced by a commercial vendor and supplied to Y-12. The economies of scale could be realized by the ability of a commercial vendor to process and certify master alloy lots up to several tons outside of the high security areas of Y-12. Several commercial vendors with applicable NRC licenses have been identified that potentially have the capabilities to supply a master alloy.

The current reference flow sheets for the FFC master alloy step is a VIM/VAR process and reflects the input from the uranium metal experts with the principal input from LANL. VIM/VAR is the process used routinely in industry to produce high quality homogeneous alloys for aerospace and other demanding applications. The VIM/VAR process, which is currently being used at Y-12 to make a uranium niobium alloy, was developed by LANL and is the principal basis of this reference process. In the reference master alloy process, electrodes are prepared by vacuum induction melting (VIM) uranium metal and casting electrodes by pouring molten uranium into a crucible containing a lattice grid made with molybdenum sheets. This electrode is then remelted in a vacuum arc remelt (VAR) furnace and the resulting ingot is then reduced into melt size pieces. A simplified flow sheet for the reference VIM/VAR process is shown in Fig. 6. 


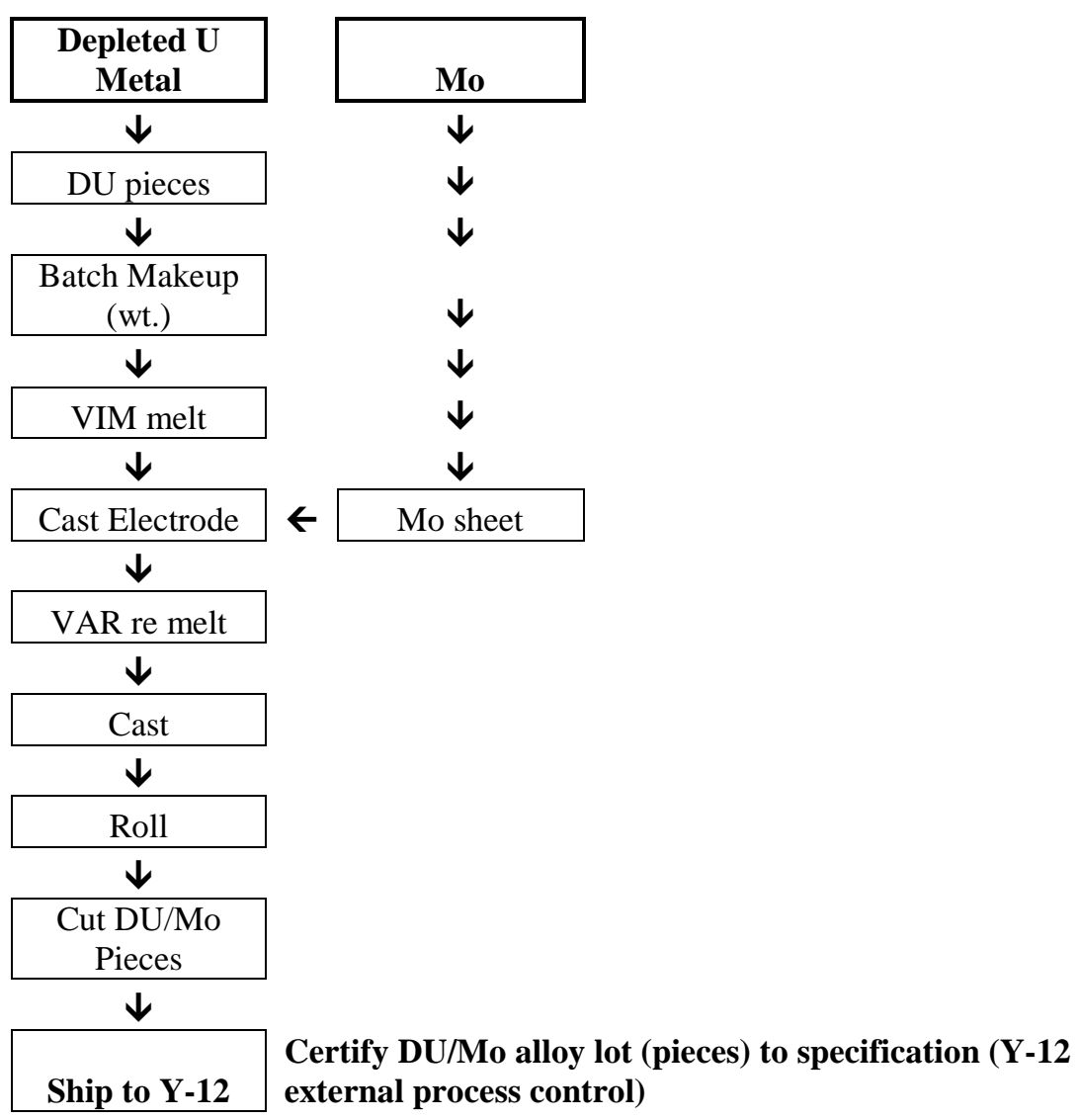

Fig. 6. Simplified flow sheet for U/Mo master alloy step. 


\section{ACTIVITIES PLANNED FOR FY12}

Although the FY 2012 work package has not been formally agreed to by the GTRI/RERTR program office and ORNL, activities will commence on the following preliminary scope of work:

1. Manage HFIR conversion project and interface with conversion program.

2. Refine and maintain HFIR conversion schedule integrated with conversion program schedule:

a. Coordinate HFIR schedule with DOE SC and conversion program.

b. Effort-, resource-, and cost-load schedule.

c. Identify and mitigate HFIR and conversion program project risks.

3. Coordinate HFIR fuel irradiation testing interests and information needs with FD pillar (e.g., input to base fuel and HFIR-specific tests, follow fuel test reporting, and input to PIE requirements for HFIR LTC).

4. Coordinate HFIR fuel fabrication quality and cost interests and information needs with FFC pillar (e.g., work with fabricators and other reactor owners to develop fuel fab spec and ensure that fab process meets qualification requirements, obtain as-fabbed fuel tolerance and uncertainty data for use in HFIR safety analyses, monitor program cost estimating for fuel fab, and develop HFIR HEU/LEU fuel element transition plan).

5. $\quad$ Continue neutronics analyses:

a. Support ANL peer review of ORNL analyses.

b. Optimize interface between neutronics and TH analyses for power distribution.

c. Document completed HEU depletion model and analyses for comparison with LEU.

d. Provide input for COMSOL TH analysis of optimized fuel (e.g., power profile without axial contouring without burnable poison, and with revised radial contouring.)

e. Confirm with researchers (scatterers and irradiators) that any impacts on flux/spectra of neutron beams and gamma heating are understood.

f. Assess any impacts on reactor vessel embrittlement monitoring.

g. Provide fission product source terms for modeling in Task 11.

6. Continue core TH/structural mechanics analyses with COMSOL:

a. FSI: Validate detailed 3-D TH/structural mechanics model of HFIR fuel elements against OSU, HEU C-K plate deflection, LEU plate deflection and UM tests.

b. TSI: Develop production 3-D model of HFIR fuel elements including detailed hot-spot and non-bond analysis, TSI, and FSI.

c. Develop translation from COMSOL to RELAP5 (e.g., hot spot factor, structural mechanics effects) to support steady-state and transient analyses for SAR Chapters 4 and 15.

d. Develop CAD-based front-end modeling for quick changes to geometry that will include fab tolerances and uncertainties.

e. Partner with neutronics optimization analyses (e.g., power profile without axial contouring, without burnable poison, and with revised radial contouring) and develop smooth power distribution compatible for coupling the detailed 3D model.

f. Issue plan for V\&V report for COMSOL application for HFIR fuel safety analysis. 
7. Complete plant RELAP5 model upgrade and interface with COMSOL:

a. Complete HFIR model consolidation.

b. Evaluate all SAR Chapter 15 transients for HEU fuel with consolidated model.

c. Interface with COMSOL.

8. Establish DOE SC/ORNL Integrated Project Team (IPT) and ORNL Safety Design Integration Team (SDIT) - new:
a. SDIT develops Safety Design Strategy (SDS).
b. SDIT begins to develop Safety Design Report (SDR).
c. Refine safety analysis cost/schedule using input from teams.
d. Coordinate with DOE NE and NRC regulators.
e. Begin revision of SAR Chapters 4 and 15 and supporting safety analyses.

9. Continue support of flow testing at Oregon State.

10. Evaluate need for fuel plate deflection testing for thermal and pressure effects.

11. Continue to develop methodology for revised fission product release and transport and offsite dose analyses.

12. Begin analyses of non-RELAP-analyzed SAR Chapter 15 accidents.

Preliminary specific deliverables and due dates for FY 2012 include:

1. List of data needs from FD and FFC to support HFIR conversion analysis and regulatory approval - 12/30/11

2. Safety Design Strategy issued by ORNL Safety Design Integration Team - 3/30/12.

3. Validation and verification plan for COMSOL applied to HFIR fuel - 3/30/12.

4. Effort-, resource-, and cost-loaded integrated HFIR conversion schedule - 6/29/12.

5. Neutronic analysis of optimized HFIR fuel - 8/31/12.

6. Thermal-hydraulic analysis of optimized HFIR fuel $-8 / 31 / 12$. 


\section{REFERENCES}

1. Work Package No. 2011 ORNL 21.1.001.009.01, "Global Threat Reduction - Conversion Program,” dated December 6, 2010.

2. G. Ilas and R. T. Primm III, "Low Enriched Uranium Fuel Design with Two-Dimensional Grading for the High Flux Isotope Reactor”, ORNL/TM-2010/318, Oak Ridge National Laboratory (2011).

3. G. Ilas, "Supporting documentation for LEU conversion, neutronic calculations in ORNL/TM2010/318”, C-HFIR-2011-11, Oak Ridge National Laboratory (March 2011).

4. R. T. Primm III, "Supporting documentation for thermal hydraulics calculations performed with the HFIR steady state heat transfer code and documented in ORNL/TM-2010/318”, C-HFIR2011-10, Oak Ridge National Laboratory (March 2011).

5. HFIR Safety Analysis Report, Rev. 8, ORNL/HFIR/USAR/2344.

6. W. Haeck, VESTA User's Manual-Version 2.0.0, IRSN Report DSU/SEC/T/2008-331 Indice A, France (2009).

7. X-5 Monte Carlo Team, MCNP-A General Monte Carlo N-Particle Transport Code, Version 5, LA-CP-03-0245, Los Alamos National Laboratory (2003).

8. RSICC Computer Code Collection CCC-371, ORIGEN 2.2. Available from RSICC, Oak Ridge National Laboratory (2002).

9. G. Ilas, R.T. Primm, III, and J.C. Gehin, "Designing a New Fuel for HFIR-Performance Parameters for LEU Core Configurations", CD Proceedings, Advances in Nuclear Fuel Management IV, Hilton Head, SC (2009).

10. W. Haeck and B. Verboomen, “An optimum approach to Monte Carlo burnup,” Nuclear Science and Engineering, 156, 180 (2007).

11. G. Ilas and R. T. Primm III, "Methodology for simulating the irradiation of the control elements in HFIR,” ANS Transactions, 103, 696-698 (2010).

12. R. T. Primm III, D. Chandler, G. Ilas, B.C. Jolly, J. H. Miller, and J. D. Sease, Design Study for a Low-Enriched Uranium Core for the High Flux Isotope Reactor, Annual Report for FY 2008, ORNL/TM-2009/87, Oak Ridge National Laboratory (2009).

13. R. D. Cheverton and T. M. Sims, HFIR Core Nuclear Design, ORNL-4621, Oak Ridge National Laboratory (1971).

14. J. D. Freels, I. T. Bodey, R. V. Arimilli, F. G. Curtis, K. Ekici, and P. K. Jain, Preliminary Multiphysics Analyses of HFIR LEU Fuel Conversion Using COMSOL, ORNL/TM-2011/007, Oak Ridge National Laboratory (June 2011).

15. RRD Calculation C-HFIR-91-011, R1, “HFIR MELCOR Model Validation and Benchmarking,” October 1991. 
16. ORNL/TM-2009/311, Establishing a Cost Basis for Converting the High Flux Isotope Reactor from High Enriched to Low Enriched Uranium Fuel, January 31, 2010.

17. Fluid-Structure Interaction for Coolant Flow in Research-type Nuclear Reactors, F. G. Curtis, K. Ekici, J. D. Freels, http://info.ornl.gov/sites/publications/Files/Pub32335.pdf, 10/19/2011.

18. Complex Geometry Creation and Turbulent Conjugate Heat Transfer Modeling, I. T. Bodey, R. V. Arimilli, J. D. Freels, http://info.ornl.gov/sites/publications/Files/Pub31952.pdf, 10/21/2011.

19. Multiphysics Simulations of the Complex 3D Geometry of the High Flux Isotope Reactor Fuel Elements Using COMSOL, J. D. Freels, P. K. Jain, http://info.ornl.gov/sites/publications/Files/Pub31941.pdf, 10/06/2011.

20. COMSOL-based Multiphysics Simulations to Support HFIR's Conversion to LEU Fuel, P. K. Jain, J. D. Freels, D. H. Cook, http://info.ornl.gov/sites/publications/Files/Pub28304.pdf, 10/05/2011. 


\section{APPENDIX}

\section{METHODOLOGY FOR CALCULATING POWER DISTRIBUTIONS FOR USE IN COMSOL}

The relative fission power distribution data required for thermal hydraulic analyses of the HFIR LEU fuel design with axial and radial grading were calculated and documented in ref. A-1. The BOC and EOC data are provided in Section 5.1.2 of ref. A-1 and data for intermediate times during the irradiation cycle are provided in Appendix D of ref. A-1. The reactor core analysis codes VESTA ${ }^{\mathrm{A}-2}$ and $\mathrm{MCNP}^{\mathrm{A}-3}$ were utilized to perform fuel cycle and fission power distribution analyses on the LEU core. The two fuel elements are modeled in MCNP by volumetrically homogenizing the fuel meat, zirconium diffusion barrier layer, aluminum clad, and the water in between the fuel plates. The IFE is discretized into 152 cells (8 radially by 19 axially) and the OFE is discretized into 171 cells (9 radially by 19 axially). Figure A-1 provides an illustration for the as-modeled LEU core and ref. A-1 provides more details on the MCNP and VESTA inputs.

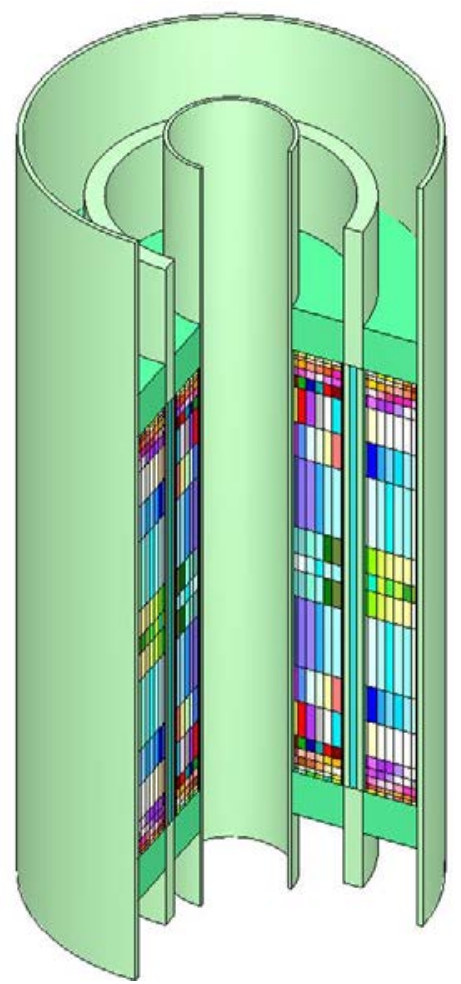

Fig. A-1. As-modeled LEU core.

Fission rate densities were calculated for each fuel-bearing zone in MCNP through the use of fission reaction rate tallies. The relative fission density $f_{i}^{d}$ in a spatial mesh $i$ located in the fuel region was calculated as shown in Eq. (1). 


$$
f_{i}^{d}=\frac{\int_{i} d^{3} r \int_{E} d E \Sigma_{f}(r, E) \Phi(r, E)}{\sum_{i=1}^{N} \int_{i} d^{3} r \int_{E} d E \Sigma_{f}(r, E) \Phi(r, E)}
$$

where $r$ and $E$ stand for spatial and energy variables, respectively; $\Sigma_{f}$ and $\Phi$ are the macroscopic fission cross section and neutron scalar flux, respectively; and $N(=323)$ is the total number of spatial meshes in the fuel regions (in both inner and outer fuel elements). As noted, $f_{i}^{d}$ in Eq. (1) is a dimensionless quantity that represents the ratio of the total number of fissions per unit volume in mesh $i$ and the total number of fissions per unit volume over all meshes (all fuel regions in the MCNP model). A script was developed, as presented in detail in ref. A-4 to automate the calculation of these data.

It is currently being assumed that $100 \%$ of the fission energy is being deposited in the fuel regions, which is a conservative approach because not all energy is deposited in the fuel. Sources of fission energy include: kinetic energy of fission fragments, beta decay energy, fission neutron kinetic energy, prompt gamma energy, delayed gamma energy, and capture gamma energy. Kinetic energy of fission fragments and beta decay energy account for approximately $90 \%$ of the total fission energy in the HFIR HEU Cycle 400 core at $\mathrm{BOC}^{\mathrm{A}-5}$ and are deposited locally in the fuel. Neutrons and gamma rays deposit their energy throughout the reactor, and therefore, must be transported to determine the spatial fission energy deposition distribution. Studies are underway to determine how much of the energy associated with neutrons and gamma rays are deposited in the fuel for the HFIR LEU core. Since it is currently being assumed that all fission energy is deposited in the fuel, the fission rate densities calculated for each fuelbearing MCNP cell as shown in Eq. (1) are the same as the relative power densities $\mathrm{P}_{\mathrm{r}, \mathrm{i}}$. for those cells as shown in Eq. (2).

$$
P_{r, i}=f_{i}^{d} \quad \text { Eq. (2) }
$$

The power per unit volume, $P_{i}$, for cell $\mathrm{i}$ is calculated as shown in Eq. (3), by multiplying the relative power density of cell i, $P_{r, i}$, by the total core power, $P_{\text {core }}$, which is $100 \times 10^{6} \mathrm{~W}$, and dividing by the total volume of the as-modeled core $\left(50951.3 \mathrm{~cm}^{3}\right)$. The total volume of the core, $V_{\text {core }}$, is calculated as shown in Eq. (4), where $H$ is the length of the active fuel region; $r_{o, \text { ife }}$ and $r_{i, i f e}$ are the outer and inner radii of the inner fuel element region; and $r_{o, o f e}$ and $r_{i, o f e}$ are the outer and inner radii of the outer fuel element region.

$$
\begin{gathered}
P_{i}\left(\frac{W}{\mathrm{~cm}^{3}}\right)=P_{r, i}\left[\frac{P_{\text {core }}(W)}{V_{\text {core }}\left(\mathrm{cm}^{3}\right)}\right] \\
V_{\text {core }}=\pi H\left[\left(r_{o, \text { ife }}^{2}-r_{i, \text { ife }}^{2}\right)+\left(r_{o, \text { ofe }}^{2}-r_{i, o f e}^{2}\right)\right]=\pi(50.8)\left[\left(12.6^{2}-7.14^{2}\right)+\left(21^{2}-15.15^{2}\right)\right] \mathrm{cm}^{3}
\end{gathered}
$$

The power per unit volume described in Eq. (3) assumes that all the power created within cell $i$ is distributed throughout the cell, which is composed of a uniformly smeared mixture of the fuel meat, $\mathrm{Zr}$ layer, Al clad, and the water in between the fuel plates. However, for complex thermal hydraulic analyses with COMSOL, the exact fuel plate geometry is modeled, and thus, the power must be confined to the fuel meat region only. The power per unit fuel meat volume is calculated by dividing the power per unit volume of cell $i$ by its fuel meat volume to total cell volume ratio as shown in Eq. (5). 


$$
P_{i, f u e l}\left(\frac{W}{c^{3} m^{3}}\right)=\frac{P_{i}\left(\frac{W}{c m^{3}}\right)}{\left(\frac{V_{i, f u e l}}{V_{i}}\right)}
$$

The volume of each of the fuel-bearing cells defined in the two fuel elements is listed in Table A-1 and the volume of the fuel contained within each of these cells is listed in Table A-2. The ratio of each cell's fuel meat volume to the total cell volume is listed in Table A-3 (i.e., Table A-3 = Table A-2/Table A-1). Data from these tables were used along with the relative fission density data documented in ref. A- 1 and the equations previously described to calculate the BOC and EOC power densities. These data are listed in Tables A-4 and A-5 for BOC and EOC conditions, respectively. The maximum power density at BOC and EOC are 72.25 and $45.30 \mathrm{~kW} / \mathrm{cm}^{3}$ of fuel meat, respectively, and are located at the inner edge of the IFE on the core horizontal midplane. The maximum to minimum power density ratios at BOC and EOC are 18.03 and 9.45, respectively. Graphical representations of the LEU power density distributions are provided in Fig. A-2. 
ORNL/TM-2011/507

Table A-1. Volume ( $\mathrm{cm}^{3}$ ) for each HFIR LEU fuel cell as modeled in MCNP

\begin{tabular}{|c|c|c|c|c|c|c|c|c|c|c|c|c|c|c|c|c|c|}
\hline \multirow{2}{*}{$\begin{array}{l}\text { Axial } \\
\text { Region }\end{array}$} & \multicolumn{8}{|c|}{ IFE } & \multicolumn{9}{|c|}{ OFE } \\
\hline & $r=1^{a}$ & $r=2$ & $r=3$ & $r=4$ & $r=5$ & $r=6$ & $r=7$ & $r=8$ & $r=1$ & $r=2$ & $r=3$ & $r=4$ & $r=5$ & $r=6$ & $r=7$ & $r=8$ & $\mathbf{r}=9$ \\
\hline 1 & 8.28 & 25.13 & 28.27 & 31.42 & 34.56 & 37.70 & 3.55 & 0.40 & 0.48 & 16.37 & 50.27 & 53.41 & 56.55 & 59.69 & 62.83 & 31.93 & 0.66 \\
\hline 2 & 8.28 & 25.13 & 28.27 & 31.42 & 34.56 & 37.70 & 3.55 & 0.40 & 0.48 & 16.37 & 50.27 & 53.41 & 56.55 & 59.69 & 62.83 & 31.93 & 0.66 \\
\hline 3 & 16.56 & 50.27 & 56.55 & 62.83 & 69.12 & 75.40 & 7.09 & 0.79 & 0.95 & 32.75 & 100.53 & 106.81 & 113.10 & 119.38 & 125.66 & 63.87 & 1.32 \\
\hline 4 & 16.56 & 50.27 & 56.55 & 62.83 & 69.12 & 75.40 & 7.09 & 0.79 & 0.95 & 32.75 & 100.53 & 106.81 & 113.10 & 119.38 & 125.66 & 63.87 & 1.32 \\
\hline 5 & 23.18 & 70.37 & 79.17 & 87.96 & 96.76 & 105.56 & 9.93 & 1.11 & 1.33 & 45.85 & 140.74 & 149.54 & 158.34 & 167.13 & 175.93 & 89.42 & 1.85 \\
\hline 6 & 69.54 & 211.12 & 237.50 & 263.89 & 290.28 & 316.67 & 29.79 & 3.32 & 4.00 & 137.55 & 422.23 & 448.62 & 475.01 & 501.40 & 527.79 & 268.25 & 5.54 \\
\hline 7 & 69.54 & 211.12 & 237.50 & 263.89 & 290.28 & 316.67 & 29.79 & 3.32 & 4.00 & 137.55 & 422.23 & 448.62 & 475.01 & 501.40 & 527.79 & 268.25 & 5.54 \\
\hline 8 & 139.08 & 422.23 & 475.01 & 527.79 & 580.57 & 633.35 & 59.59 & 6.65 & 8.00 & 275.09 & 844.46 & 897.24 & 950.02 & 1002.80 & 1055.58 & 536.50 & 11.08 \\
\hline 9 & 52.98 & 160.85 & 180.96 & 201.06 & 221.17 & 241.27 & 22.70 & 2.53 & 3.05 & 104.80 & 321.70 & 341.81 & 361.91 & 382.02 & 402.12 & 204.38 & 4.22 \\
\hline 10 & 33.11 & 100.53 & 113.10 & 125.66 & 138.23 & 150.80 & 14.19 & 1.58 & 1.90 & 65.50 & 201.06 & 213.63 & 226.19 & 238.76 & 251.33 & 127.74 & 2.64 \\
\hline 11 & 52.98 & 160.85 & 180.96 & 201.06 & 221.17 & 241.27 & 22.70 & 2.53 & 3.05 & 104.80 & 321.70 & 341.81 & 361.91 & 382.02 & 402.12 & 204.38 & 4.22 \\
\hline 12 & 139.08 & 422.23 & 475.01 & 527.79 & 580.57 & 633.35 & 59.59 & 6.65 & 8.00 & 275.09 & 844.46 & 897.24 & 950.02 & 1002.80 & 1055.58 & 536.50 & 11.08 \\
\hline 13 & 69.54 & 211.12 & 237.50 & 263.89 & 290.28 & 316.67 & 29.79 & 3.32 & 4.00 & 137.55 & 422.23 & 448.62 & 475.01 & 501.40 & 527.79 & 268.25 & 5.54 \\
\hline 14 & 69.54 & 211.12 & 237.50 & 263.89 & 290.28 & 316.67 & 29.79 & 3.32 & 4.00 & 137.55 & 422.23 & 448.62 & 475.01 & 501.40 & 527.79 & 268.25 & 5.54 \\
\hline 15 & 23.18 & 70.37 & 79.17 & 87.96 & 96.76 & 105.56 & 9.93 & 1.11 & 1.33 & 45.85 & 140.74 & 149.54 & 158.34 & 167.13 & 175.93 & 89.42 & 1.85 \\
\hline 16 & 16.56 & 50.27 & 56.55 & 62.83 & 69.12 & 75.40 & 7.09 & 0.79 & 0.95 & 32.75 & 100.53 & 106.81 & 113.10 & 119.38 & 125.66 & 63.87 & 1.32 \\
\hline 17 & 16.56 & 50.27 & 56.55 & 62.83 & 69.12 & 75.40 & 7.09 & 0.79 & 0.95 & 32.75 & 100.53 & 106.81 & 113.10 & 119.38 & 125.66 & 63.87 & 1.32 \\
\hline 18 & 8.28 & 25.13 & 28.27 & 31.42 & 34.56 & 37.70 & 3.55 & 0.40 & 0.48 & 16.37 & 50.27 & 53.41 & 56.55 & 59.69 & 62.83 & 31.93 & 0.66 \\
\hline 19 & 8.28 & 25.13 & 28.27 & 31.42 & 34.56 & 37.70 & 3.55 & 0.40 & 0.48 & 16.37 & 50.27 & 53.41 & 56.55 & 59.69 & 62.83 & 31.93 & 0.66 \\
\hline
\end{tabular}

${ }^{a}=n$ denotes the radial region number; $n$ varies from 1 to 8 for the IFE and 1 to 9 for the OFE. 
Table A-2. Volume $\left(\mathrm{cm}^{3}\right)$ of fuel meat within each HFIR LEU fuel cell as modeled in MCNP

\begin{tabular}{|c|c|c|c|c|c|c|c|c|c|c|c|c|c|c|c|c|c|}
\hline \multirow{2}{*}{$\begin{array}{c}\text { Axial } \\
\text { Region }\end{array}$} & \multicolumn{8}{|c|}{ IFE } & \multicolumn{9}{|c|}{ OFE } \\
\hline & $r=1^{a}$ & $r=2$ & $r=3$ & $r=4$ & $r=5$ & $r=6$ & $r=7$ & $r=8$ & $r=1$ & $r=2$ & $r=3$ & $r=4$ & $r=5$ & $r=6$ & $r=7$ & $r=8$ & $r=9$ \\
\hline 1 & 0.317 & 1.853 & 3.685 & 5.036 & 5.539 & 4.604 & 0.285 & 0.030 & 0.041 & 1.697 & 8.809 & 12.245 & 12.965 & 13.686 & 10.949 & 2.916 & 0.041 \\
\hline 2 & 0.317 & 1.853 & 3.685 & 5.036 & 5.539 & 4.604 & 0.285 & 0.030 & 0.041 & 1.697 & 8.809 & 12.245 & 12.965 & 13.686 & 10.949 & 2.916 & 0.041 \\
\hline 3 & 0.634 & 3.705 & 7.369 & 10.071 & 11.078 & 9.208 & 0.570 & 0.060 & 0.081 & 3.394 & 17.619 & 24.490 & 25.930 & 27.371 & 21.898 & 5.831 & 0.083 \\
\hline 4 & 0.634 & 3.705 & 7.369 & 10.071 & 11.078 & 9.208 & 0.570 & 0.060 & 0.081 & 3.394 & 17.619 & 24.490 & 25.930 & 27.371 & 21.898 & 5.831 & 0.083 \\
\hline 5 & 0.888 & 5.187 & 10.317 & 14.099 & 15.509 & 12.892 & 0.798 & 0.085 & 0.114 & 4.752 & 24.666 & 34.286 & 36.303 & 38.320 & 30.658 & 8.164 & 0.116 \\
\hline 6 & 2.664 & 15.562 & 30.951 & 42.298 & 46.528 & 38.675 & 2.395 & 0.254 & 0.342 & 14.256 & 73.998 & 102.858 & 108.908 & 114.959 & 91.974 & 24.492 & 0.348 \\
\hline 7 & 2.664 & 15.562 & 30.951 & 42.298 & 46.528 & 38.675 & 2.395 & 0.254 & 0.342 & 14.256 & 73.998 & 102.858 & 108.908 & 114.959 & 91.974 & 24.492 & 0.348 \\
\hline 8 & 5.327 & 31.125 & 61.901 & 84.597 & 93.056 & 77.349 & 4.790 & 0.508 & 0.684 & 28.511 & 147.997 & 205.715 & 217.816 & 229.917 & 183.947 & 48.984 & 0.695 \\
\hline 9 & 2.029 & 11.857 & 23.581 & 32.227 & 35.450 & 29.466 & 1.825 & 0.193 & 0.261 & 10.861 & 56.380 & 78.368 & 82.978 & 87.587 & 70.075 & 18.661 & 0.265 \\
\hline 10 & 1.268 & 7.411 & 14.738 & 20.142 & 22.156 & 18.417 & 1.140 & 0.121 & 0.163 & 6.788 & 35.237 & 48.980 & 51.861 & 54.742 & 43.797 & 11.663 & 0.166 \\
\hline 11 & 2.029 & 11.857 & 23.581 & 32.227 & 35.450 & 29.466 & 1.825 & 0.193 & 0.261 & 10.861 & 56.380 & 78.368 & 82.978 & 87.587 & 70.075 & 18.661 & 0.265 \\
\hline 12 & 5.327 & 31.125 & 61.901 & 84.597 & 93.056 & 77.349 & 4.790 & 0.508 & 0.684 & 28.511 & 147.997 & 205.715 & 217.816 & 229.917 & 183.947 & 48.984 & 0.695 \\
\hline 13 & 2.664 & 15.562 & 30.951 & 42.298 & 46.528 & 38.675 & 2.395 & 0.254 & 0.342 & 14.256 & 73.998 & 102.858 & 108.908 & 114.959 & 91.974 & 24.492 & 0.348 \\
\hline 14 & 2.664 & 15.562 & 30.951 & 42.298 & 46.528 & 38.675 & 2.395 & 0.254 & 0.342 & 14.256 & 73.998 & 102.858 & 108.908 & 114.959 & 91.974 & 24.492 & 0.348 \\
\hline 15 & 0.888 & 5.187 & 10.317 & 14.099 & 15.509 & 12.892 & 0.798 & 0.085 & 0.114 & 4.752 & 24.666 & 34.286 & 36.303 & 38.320 & 30.658 & 8.164 & 0.116 \\
\hline 16 & 0.634 & 3.705 & 6.698 & 9.409 & 10.350 & 8.040 & 0.488 & 0.051 & 0.068 & 2.940 & 15.417 & 21.521 & 22.787 & 24.053 & 19.543 & 5.310 & 0.072 \\
\hline 17 & 0.621 & 2.864 & 3.518 & 4.373 & 4.810 & 4.535 & 0.321 & 0.033 & 0.042 & 1.929 & 7.889 & 9.276 & 9.821 & 10.367 & 9.943 & 3.843 & 0.050 \\
\hline 18 & 0.244 & 0.742 & 0.835 & 0.928 & 1.020 & 1.113 & 0.105 & 0.012 & 0.014 & 0.483 & 1.484 & 1.577 & 1.669 & 1.762 & 1.855 & 0.943 & 0.019 \\
\hline 19 & 0.244 & 0.742 & 0.835 & 0.928 & 1.020 & 1.113 & 0.105 & 0.012 & 0.014 & 0.483 & 1.484 & 1.577 & 1.669 & 1.762 & 1.855 & 0.943 & 0.019 \\
\hline
\end{tabular}

${ }_{\mathrm{r}}^{\mathrm{a}}=\mathrm{n}$ denotes the radial region number; $\mathrm{n}$ varies from 1 to 8 for the IFE and 1 to 9 for the OFE. 
Table A-3. Fuel meat to total cell volume ratio for each HFIR LEU fuel cell as modeled in MCNP

\begin{tabular}{|c|c|c|c|c|c|c|c|c|c|c|c|c|c|c|c|c|c|}
\hline \multirow{2}{*}{$\begin{array}{l}\text { Axial } \\
\text { Region }\end{array}$} & \multicolumn{8}{|c|}{ IFE } & \multicolumn{9}{|c|}{ OFE } \\
\hline & $r=1^{a}$ & $r=2$ & $r=3$ & $r=4$ & $r=5$ & $r=6$ & $r=7$ & $r=8$ & $r=1$ & $r=2$ & $r=3$ & $r=4$ & $r=5$ & $r=6$ & $r=7$ & $r=8$ & $r=9$ \\
\hline 1 & 0.038 & 0.074 & 0.130 & 0.160 & 0.160 & 0.122 & 0.080 & 0.076 & 0.086 & 0.104 & 0.175 & 0.229 & 0.229 & 0.229 & 0.174 & 0.091 & 0.063 \\
\hline 2 & 0.038 & 0.074 & 0.130 & 0.160 & 0.160 & 0.122 & 0.080 & 0.076 & 0.086 & 0.104 & 0.175 & 0.229 & 0.229 & 0.229 & 0.174 & 0.091 & 0.063 \\
\hline 3 & 0.038 & 0.074 & 0.130 & 0.160 & 0.160 & 0.122 & 0.080 & 0.076 & 0.086 & 0.104 & 0.175 & 0.229 & 0.229 & 0.229 & 0.174 & 0.091 & 0.063 \\
\hline 4 & 0.038 & 0.074 & 0.130 & 0.160 & 0.160 & 0.122 & 0.080 & 0.076 & 0.086 & 0.104 & 0.175 & 0.229 & 0.229 & 0.229 & 0.174 & 0.091 & 0.063 \\
\hline 5 & 0.038 & 0.074 & 0.130 & 0.160 & 0.160 & 0.122 & 0.080 & 0.076 & 0.086 & 0.104 & 0.175 & 0.229 & 0.229 & 0.229 & 0.174 & 0.091 & 0.063 \\
\hline 6 & 0.038 & 0.074 & 0.130 & 0.160 & 0.160 & 0.122 & 0.080 & 0.076 & 0.086 & 0.104 & 0.175 & 0.229 & 0.229 & 0.229 & 0.174 & 0.091 & 0.063 \\
\hline 7 & 0.038 & 0.074 & 0.130 & 0.160 & 0.160 & 0.122 & 0.080 & 0.076 & 0.086 & 0.104 & 0.175 & 0.229 & 0.229 & 0.229 & 0.174 & 0.091 & 0.063 \\
\hline 8 & 0.038 & 0.074 & 0.130 & 0.160 & 0.160 & 0.122 & 0.080 & 0.076 & 0.086 & 0.104 & 0.175 & 0.229 & 0.229 & 0.229 & 0.174 & 0.091 & 0.063 \\
\hline 9 & 0.038 & 0.074 & 0.130 & 0.160 & 0.160 & 0.122 & 0.080 & 0.076 & 0.086 & 0.104 & 0.175 & 0.229 & 0.229 & 0.229 & 0.174 & 0.091 & 0.063 \\
\hline 10 & 0.038 & 0.074 & 0.130 & 0.160 & 0.160 & 0.122 & 0.080 & 0.076 & 0.086 & 0.104 & 0.175 & 0.229 & 0.229 & 0.229 & 0.174 & 0.091 & 0.063 \\
\hline 11 & 0.038 & 0.074 & 0.130 & 0.160 & 0.160 & 0.122 & 0.080 & 0.076 & 0.086 & 0.104 & 0.175 & 0.229 & 0.229 & 0.229 & 0.174 & 0.091 & 0.063 \\
\hline 12 & 0.038 & 0.074 & 0.130 & 0.160 & 0.160 & 0.122 & 0.080 & 0.076 & 0.086 & 0.104 & 0.175 & 0.229 & 0.229 & 0.229 & 0.174 & 0.091 & 0.063 \\
\hline 13 & 0.038 & 0.074 & 0.130 & 0.160 & 0.160 & 0.122 & 0.080 & 0.076 & 0.086 & 0.104 & 0.175 & 0.229 & 0.229 & 0.229 & 0.174 & 0.091 & 0.063 \\
\hline 14 & 0.038 & 0.074 & 0.130 & 0.160 & 0.160 & 0.122 & 0.080 & 0.076 & 0.086 & 0.104 & 0.175 & 0.229 & 0.229 & 0.229 & 0.174 & 0.091 & 0.063 \\
\hline 15 & 0.038 & 0.074 & 0.130 & 0.160 & 0.160 & 0.122 & 0.080 & 0.076 & 0.086 & 0.104 & 0.175 & 0.229 & 0.229 & 0.229 & 0.174 & 0.091 & 0.063 \\
\hline 16 & 0.038 & 0.074 & 0.118 & 0.150 & 0.150 & 0.107 & 0.069 & 0.065 & 0.072 & 0.090 & 0.153 & 0.201 & 0.201 & 0.201 & 0.156 & 0.083 & 0.055 \\
\hline 17 & 0.038 & 0.057 & 0.062 & 0.070 & 0.070 & 0.060 & 0.045 & 0.042 & 0.044 & 0.059 & 0.078 & 0.087 & 0.087 & 0.087 & 0.079 & 0.060 & 0.038 \\
\hline 18 & 0.030 & 0.030 & 0.030 & 0.030 & 0.030 & 0.030 & 0.030 & 0.030 & 0.030 & 0.030 & 0.030 & 0.030 & 0.030 & 0.030 & 0.030 & 0.030 & 0.030 \\
\hline 19 & 0.030 & 0.030 & 0.030 & 0.030 & 0.030 & 0.030 & 0.030 & 0.030 & 0.030 & 0.030 & 0.030 & 0.030 & 0.030 & 0.030 & 0.030 & 0.030 & 0.030 \\
\hline
\end{tabular}

${ }_{\mathrm{r}}^{\mathrm{a}}=\mathrm{n}$ denotes the radial region number; $\mathrm{n}$ varies from 1 to 8 for the IFE and 1 to 9 for the OFE. 
ORNL/TM-2011/507

Table A-4. BOC power density (W/ $\mathrm{cm}^{3}$ of fuel meat) for the HFIR LEU core

\begin{tabular}{|c|c|c|c|c|c|c|c|c|c|c|c|c|c|c|c|c|c|}
\hline \multirow{2}{*}{$\begin{array}{c}\text { Axial } \\
\text { Region }\end{array}$} & \multicolumn{8}{|c|}{ IFE } & \multicolumn{9}{|c|}{ OFE } \\
\hline & $r=1^{a}$ & $r=2$ & $r=3$ & $r=4$ & $r=5$ & $r=6$ & $\mathrm{r}=7$ & $r=8$ & $r=1$ & $r=2$ & $r=3$ & $r=4$ & $r=5$ & $r=6$ & $r=7$ & $r=8$ & $r=9$ \\
\hline 1 & 50,934 & 34,905 & 23,555 & 19,114 & 18,159 & 21,518 & 27,837 & 29,392 & 27,882 & 23,463 & 15,544 & 11,385 & 9,913 & 8,920 & 8,909 & 10,103 & 10,975 \\
\hline 2 & 43,862 & 26,439 & 15,392 & 11,706 & 11,547 & 15,797 & 23,173 & 25,102 & 23,384 & 18,918 & 10,628 & 6,831 & 5,804 & 5,410 & 6,014 & 7,954 & 9,286 \\
\hline 3 & 40,429 & 22,631 & 12,064 & 8,951 & 9,024 & 13,258 & 20,340 & 21,839 & 20,375 & 16,267 & 8,937 & 5,444 & 4,537 & 4,306 & 4,989 & 6,922 & 8,286 \\
\hline 4 & 39,045 & 21,486 & 11,175 & 8,326 & 8,473 & 12,519 & 18,997 & 20,271 & 18,769 & 15,150 & 8,478 & 5,239 & 4,374 & 4,177 & 4,888 & 6,793 & 8,130 \\
\hline 5 & 39,712 & 22,019 & 11,612 & 8,694 & 8,865 & 12,776 & 18,924 & 20,272 & 18,518 & 15,074 & 8,746 & 5,556 & 4,665 & 4,468 & 5,271 & 7,287 & 8,537 \\
\hline 6 & 45,553 & 25,347 & 13,570 & 10,261 & 10,420 & 14,640 & 21,170 & 22,507 & 20,721 & 17,138 & 10,202 & 6,651 & 5,658 & 5,547 & 6,960 & 10,555 & 12,852 \\
\hline 7 & 55,494 & 30,965 & 16,582 & 12,600 & 12,796 & 17,870 & 25,688 & 27,389 & 25,058 & 20,793 & 12,554 & 8,269 & 7,122 & 7,182 & 9,607 & 15,714 & 19,575 \\
\hline 8 & 66,511 & 37,142 & 19,941 & 15,184 & 15,441 & 21,615 & 31,084 & 33,067 & 30,313 & 25,224 & 15,320 & 10,212 & 8,937 & 9,228 & 13,155 & 23,087 & 29,519 \\
\hline 9 & 72,045 & 40,204 & 21,597 & 16,469 & 16,812 & 23,527 & 33,819 & 35,944 & 33,227 & 27,572 & 16,776 & 11,282 & 10,007 & 10,683 & 16,601 & 31,943 & 42,058 \\
\hline 10 & 72,249 & 40,337 & 21,718 & 16,530 & 16,861 & 23,640 & 34,014 & 36,252 & 33,410 & 27,781 & 16,843 & 11,351 & 10,075 & 10,829 & 16,984 & 33,061 & 43,684 \\
\hline 11 & 71,122 & 39,644 & 21,386 & 16,310 & 16,628 & 23,254 & 33,379 & 35,559 & 32,814 & 27,250 & 16,563 & 11,163 & 9,921 & 10,615 & 16,556 & 32,051 & 42,245 \\
\hline 12 & 64,358 & 35,890 & 19,308 & 14,706 & 14,939 & 20,876 & 30,010 & 31,988 & 29,303 & 24,353 & 14,749 & 9,819 & 8,569 & 8,808 & 12,400 & 21,432 & 27,173 \\
\hline 13 & 52,266 & 29,074 & 15,558 & 11,767 & 11,951 & 16,697 & 24,003 & 25,590 & 23,429 & 19,429 & 11,680 & 7,713 & 6,643 & 6,609 & 8,717 & 13,994 & 17,323 \\
\hline 14 & 42,325 & 23,430 & 12,425 & 9,380 & 9,526 & 13,467 & 19,583 & 20,914 & 19,161 & 15,793 & 9,340 & 6,018 & 5,076 & 4,922 & 5,947 & 8,577 & 10,256 \\
\hline 15 & 37,047 & 20,448 & 10,753 & 8,131 & 8,326 & 12,117 & 18,143 & 19,450 & 17,944 & 14,581 & 8,321 & 5,213 & 4,323 & 4,006 & 4,302 & 5,181 & 5,754 \\
\hline 16 & 36,483 & 20,743 & 11,782 & 9,175 & 9,371 & 13,473 & 19,666 & 20,967 & 19,774 & 16,398 & 9,791 & 6,283 & 5,260 & 4,754 & 4,808 & 5,430 & 5,931 \\
\hline 17 & 39,182 & 24,627 & 16,876 & 14,325 & 14,240 & 18,011 & 23,767 & 24,992 & 24,451 & 21,194 & 15,082 & 11,210 & 9,470 & 8,249 & 7,342 & 6,915 & 7,028 \\
\hline 18 & 44,267 & 31,771 & 24,526 & 21,735 & 21,269 & 23,928 & 28,714 & 30,042 & 30,119 & 27,524 & 22,471 & 18,283 & 15,690 & 13,363 & 11,036 & 9,308 & 8,709 \\
\hline 19 & 51,047 & 40,146 & 33,034 & 29,711 & 28,514 & 29,844 & 33,367 & 34,030 & 34,241 & 32,244 & 27,989 & 23,934 & 20,743 & 17,551 & 14,094 & 11,169 & 10,105 \\
\hline
\end{tabular}

${ }_{\mathrm{r}}^{\mathrm{a}}=\mathrm{n}$ denotes the radial region number; $\mathrm{n}$ varies from 1 to 8 for the IFE and 1 to 9 for the OFE. 
Table A-5. EOC power density (W/ $\mathrm{cm}^{3}$ of fuel meat) for the HFIR LEU core

\begin{tabular}{|c|c|c|c|c|c|c|c|c|c|c|c|c|c|c|c|c|c|}
\hline \multirow{2}{*}{$\begin{array}{c}\text { Axial } \\
\text { Region }\end{array}$} & \multicolumn{8}{|c|}{ IFE } & \multicolumn{9}{|c|}{ OFE } \\
\hline & $r=1^{a}$ & $r=2$ & $r=3$ & $r=4$ & $r=5$ & $r=6$ & $r=7$ & $r=8$ & $\mathbf{r}=1$ & $r=2$ & $r=3$ & $r=4$ & $r=5$ & $r=6$ & $r=7$ & $r=8$ & $r=9$ \\
\hline 1 & 37,662 & 30,938 & 22,621 & 18,392 & 17,645 & 20,506 & 25,004 & 26,515 & 25,197 & 21,512 & 15,611 & 12,121 & 11,265 & 11,342 & 14,045 & 20,400 & 24,764 \\
\hline 2 & 35,766 & 26,731 & 16,416 & 12,135 & 11,853 & 15,894 & 21,781 & 23,534 & 22,076 & 17,971 & 10,964 & 7,345 & 6,600 & 6,925 & 10,159 & 18,121 & 23,607 \\
\hline 3 & 34,229 & 23,643 & 13,073 & 9,220 & 9,208 & 13,371 & 19,388 & 21,068 & 19,549 & 15,642 & 8,993 & 5,693 & 5,042 & 5,470 & 8,931 & 17,584 & 23,515 \\
\hline 4 & 33,665 & 22,551 & 11,958 & 8,351 & 8,437 & 12,390 & 17,996 & 19,706 & 18,196 & 14,468 & 8,422 & 5,384 & 4,794 & 5,290 & 8,931 & 18,143 & 24,453 \\
\hline 5 & 34,383 & 22,951 & 12,229 & 8,620 & 8,657 & 12,422 & 17,752 & 19,398 & 17,899 & 14,260 & 8,589 & 5,641 & 5,051 & 5,581 & 9,506 & 19,282 & 25,985 \\
\hline 6 & 37,201 & 25,666 & 14,007 & 9,943 & 9,943 & 13,837 & 19,364 & 21,299 & 19,597 & 15,623 & 9,709 & 6,557 & 5,898 & 6,540 & 11,026 & 21,733 & 29,081 \\
\hline 7 & 41,403 & 29,980 & 16,808 & 11,877 & 11,804 & 16,199 & 22,367 & 24,742 & 22,786 & 18,104 & 11,445 & 7,781 & 7,019 & 7,790 & 13,020 & 24,441 & 32,020 \\
\hline 8 & 44,375 & 33,947 & 19,624 & 13,849 & 13,714 & 18,642 & 25,419 & 28,416 & 26,091 & 20,584 & 13,181 & 8,997 & 8,107 & 9,022 & 14,979 & 26,892 & 34,616 \\
\hline 9 & 45,194 & 35,518 & 20,935 & 14,779 & 14,608 & 19,815 & 26,884 & 30,061 & 27,582 & 21,702 & 13,999 & 9,545 & 8,612 & 9,605 & 15,858 & 27,966 & 35,835 \\
\hline 10 & 45,297 & 35,731 & 21,100 & 14,865 & 14,706 & 19,879 & 26,884 & 30,086 & 27,605 & 21,796 & 14,066 & 9,596 & 8,654 & 9,622 & 15,925 & 27,988 & 35,866 \\
\hline 11 & 45,041 & 35,358 & 20,859 & 14,731 & 14,547 & 19,670 & 26,738 & 29,907 & 27,445 & 21,626 & 13,931 & 9,519 & 8,577 & 9,553 & 15,790 & 27,838 & 35,679 \\
\hline 12 & 43,606 & 33,334 & 19,278 & 13,628 & 13,482 & 18,320 & 24,980 & 27,902 & 25,632 & 20,206 & 12,946 & 8,851 & 7,970 & 8,877 & 14,743 & 26,526 & 34,178 \\
\hline 13 & 40,122 & 28,941 & 16,221 & 11,473 & 11,424 & 15,653 & 21,634 & 23,997 & 22,052 & 17,479 & 11,042 & 7,507 & 6,780 & 7,542 & 12,682 & 23,925 & 31,363 \\
\hline 14 & 36,227 & 24,788 & 13,419 & 9,490 & 9,502 & 13,322 & 18,777 & 20,734 & 19,092 & 15,206 & 9,351 & 6,266 & 5,633 & 6,275 & 10,722 & 21,346 & 28,580 \\
\hline 15 & 34,024 & 22,738 & 12,214 & 8,669 & 8,767 & 12,744 & 18,533 & 20,272 & 18,679 & 14,866 & 8,847 & 5,727 & 5,119 & 5,658 & 9,663 & 19,604 & 26,454 \\
\hline 16 & 34,229 & 23,858 & 14,168 & 10,603 & 10,695 & 14,945 & 20,579 & 22,240 & 20,705 & 16,966 & 10,763 & 7,267 & 6,536 & 7,043 & 10,904 & 20,043 & 26,169 \\
\hline 17 & 36,357 & 28,485 & 21,135 & 17,822 & 17,455 & 20,686 & 25,155 & 26,551 & 24,898 & 21,760 & 16,633 & 13,380 & 12,385 & 12,724 & 15,801 & 22,507 & 27,187 \\
\hline 18 & 38,817 & 34,097 & 28,847 & 26,055 & 25,191 & 26,720 & 29,379 & 30,441 & 28,922 & 26,792 & 23,335 & 20,875 & 19,812 & 19,812 & 21,673 & 25,662 & 28,720 \\
\hline 19 & 40,479 & 37,421 & 33,632 & 31,439 & 30,242 & 30,708 & 32,170 & 32,700 & 31,515 & 29,917 & 27,590 & 25,795 & 24,731 & 24,466 & 25,330 & 27,524 & 29,318 \\
\hline
\end{tabular}

${ }_{\mathrm{r}}^{\mathrm{a}}=\mathrm{n}$ denotes the radial region number; $\mathrm{n}$ varies from 1 to 8 for the IFE and 1 to 9 for the OFE. 


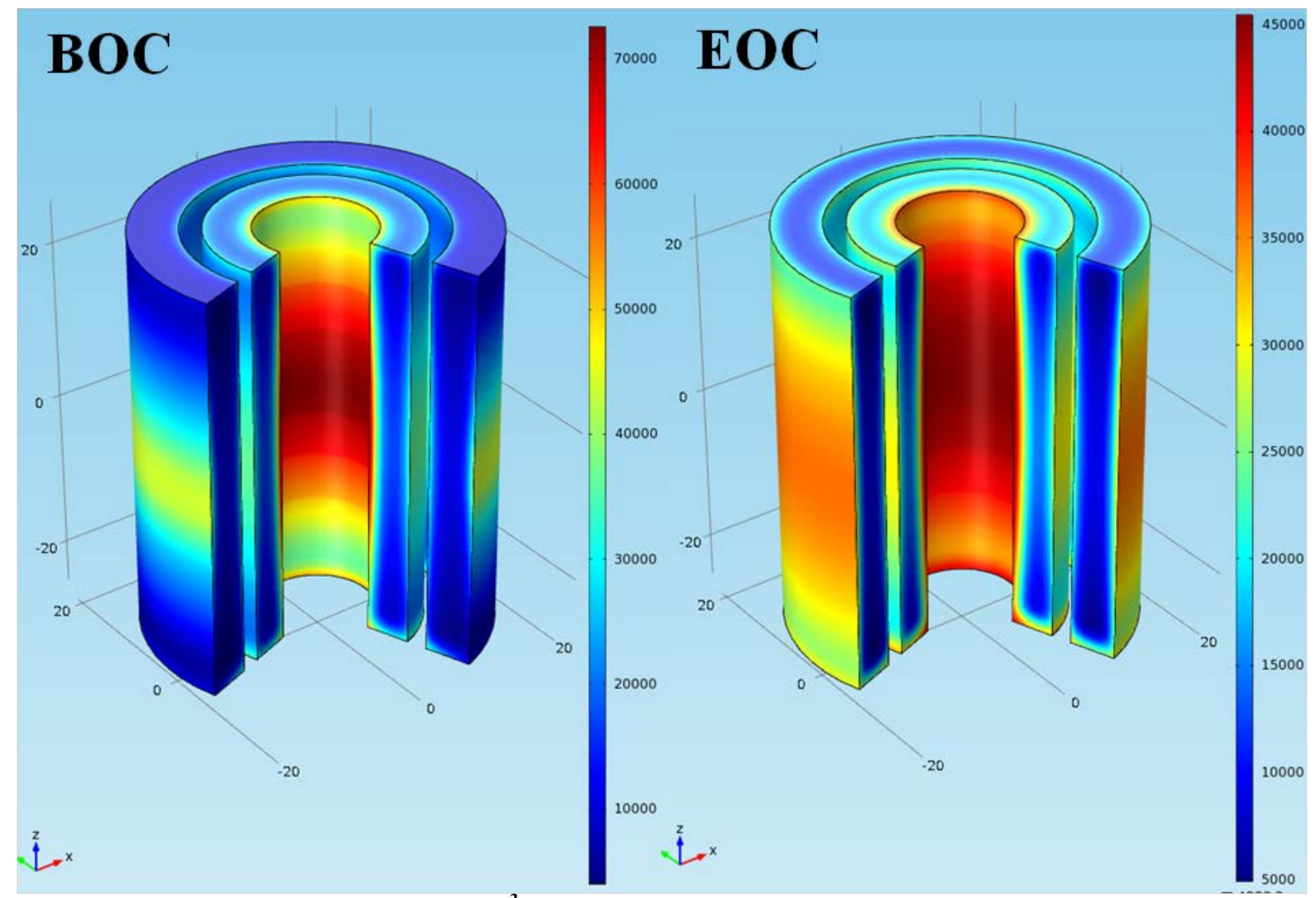

Fig. A-2. Power density (W/cm ${ }^{3}$ of fuel meat) distribution for the LEU core at $100 \mathrm{MW}$.

\section{References}

A-1. G. Ilas and R. T. Primm, III, "Low Enriched Uranium Fuel Design with Two-Dimensional Grading for the High Flux Isotope Reactor,” ORNL/TM-2010/318, Oak Ridge National Laboratory (2011).

A-2. W. HAECK, “VESTA User’s Manual - Version 2.0.0”, IRSN Report DSU/SEC/T/2008-331 Indice A, France (2009).

A-3. X-5 Monte Carlo Team, "MCNP-A General Monte Carlo N-Particle Transport Code, Version 5,” LA-CP-03-0245, Los Alamos National Laboratory (2003).

A-4. G. Ilas, "Supporting documentation for LEU conversion, neutronic calculations in ORNL/TM2010/318”, C-HFIR-2011-011_0, Oak Ridge National Laboratory (March 3, 2011).

A-5. J. Peterson and G. Ilas, "Calculation of heating values for the High Flux Isotope Reactor", submitted to the PHYSOR 2012 Topical Meeting (Knoxville, TN, April 2012). 
ORNL/TM-2011/507

\section{INTERNAL DISTRIBUTION}

1. K. J. Beierschmitt (beierschmitt@ornl.gov)

2. G. I. Bell (bellgi@ornl.gov)

3. J. L. Binder (binderjl@ornl.gov)

4. I. T. Bodey (bodeyit@ornl.gov)

5. S. M. Bowman (bowmansm@ornl.gov)

6. S. E. Burnette (burnettese@ornl.gov)

7. D. Chandler (chandlerd@ornl.gov)

8. D. H. Cook (dhc@ornl.gov)

9. R. A. Crone (cronera@ornl.gov)

10. F. G. Curtis (curtisfg@ornl.gov)

11. J. D. Freels (freelsjd@ornl.gov)

12. F. P. Griffin (griffinfp@ornl.gov)

13. C. R. Hyman (hymancriii@ornl.gov)

14. A. S. Icenhour (icenhouras@ornl.gov)

15. G. Ilas (ilasg@ornl.gov)
16. P. K. Jain (jainpk@ornl.gov)

17. Y.S. Kwon (kwonys@ornl.gov)

18. R. S. McKeehan (mckeehanrs@ornl.gov)

19. J. H. Miller (millerjh2@ornl.gov)

20. R. N. Morris (morrisrn@ornl.gov)

21. C. V. Parks (parkscv@ornl.gov)

22. D. L. Pinkston (pinkstondl@ornl.gov)

23-26. D. G. Renfro (renfrodg@ornl.gov)

27. J. D. Sease (seasejd@ornl.gov)

28. K. A. Smith (smithka@ornl.gov)

29. W. J. Toth (tothwj@ornl.gov)

30. J. R. Valentine (valentinejr@ornl.gov)

31. S. L. Voit (voitsl@ornl.gov)

32. S. J. Zinkle (zinklesj@ornl.gov)

33. ORNL Laboratory Records (hamrindr@ornl.gov)

34. RRD-DCC-RC (hugginscn@ornl.gov)

\section{EXTERNAL DISTRIBUTION}

35. A. Adams, U.S. Nuclear Regulatory Commission (axa@nrc.gov)

36. G. S. Chang, Idaho National Laboratory (gray.chang@inl.gov)

37. J. Chamberlin, NA-212, U.S. Department of Energy (jeffry.chamberlin@nnsa.doe.gov)

38. D. Diamond, Brookhaven National Laboratory (diamond@bnl.gov)

39. M. D. DeHart, Idaho National Laboratory (Mark.DeHart@inl.gov)

40. Phillip Finck, Nuclear Science \& Technology, INEEL (Phillip.Finck@inl.gov)

41. D. Kutikkad, University of Missouri Research Reactor Facility (kutikkadk@missouri.edu)

42. C. Landers, NA-212, U.S. Department of Energy (Christopher.landers@nnsa.doe.gov)

43. J. Matos, Argonne National Laboratory (jim.matos@anl.gov)

44. C. McKibben, University of Missouri Research Reactor Facility (mckibben@missouri.edu)

45. John Dwight, Idaho National Laboratory (John.Dwight@inl.gov)

46. T. Newton, MIT Nuclear Reactor Laboratory (tnewton@mit.edu)

47. W. Richards, NIST Center for Neutron Research, (wade.richards@nist.gov)

48. J. Roglans, Argonne National Laboratory (roglans@anl.gov)

49. P. Staples, NA-212, U.S. Department of Energy (Parrish.Staples@nnsa.doe.gov)

50. John G. Stevens, Argonne National Laboratory (johnstevens@anl.gov)

51. Daniel M. Wachs, MFC 791 B-147, Idaho National Laboratory (Daniel.Wachs@inl.gov)

52. R. E. Williams, NIST Center for Neutron Research (robert.williams@nist.gov)

53. Sean O’Kelly, NIST Center for Neutron Research (sean.okelly@nist.gov)

54. W. C. Richardson, BWXT Technology, Inc. (WCRichardson@bwxt.com)

55. Eric C Woolstenhulme, Idaho Falls, ID (Eric.Woolstenhulme@inl.gov)

56. Carol Sohn, Department of Energy (carol.sohn@pnso.science.doe.gov).

57. Johnny O. Moore, U. S. Department of Energy, (moorejo@ornl.gov)

58. Les Foyto, University of Missouri (foytol@missouri.edu)

59. Lloyd Jollay, Y-12 National Security Complex (jollay@y12.doe.gov)

60. David Rosine, U. S. Department of Energy (rosined@ornl.gov)

61. Doug Reed, U. S. Department of Energy (reeddr@ornl.gov)

62. Gary Solbrekken, University of Missouri (solbrekkeng@missouri.edu)

63. David McDaniel, Idaho National Laboratory, (David.McDaniel@inl.gov)

64. Mitchell K. Meyer, INL (Mitchell.Meyer@inl.gov

65. Kenneth E. Rosenberg, INL (Kenneth.Rosenberg@inl.gov)

66. Douglas Burkes, PNNL (Douglas.Burkes@pnnl.gov)

67. Sean Morrell, INL (Sean.Morrell@inl.gov)

68. Rebecca West, INL (Rebecca.West@inl.gov) 
69. Joe Cleary, PNNL (Joe.Cleary@pnnl.gov)

70. Natraj Iyer, NNSA (Natraj.Iyer@nnsa.doe.gov)

71. Robert T. Ostrowski, B\&W (rtostrowski@babcock.com)

72. Jared M. Wight, B\&W (jmwight@babcock.com)

73. Anthony Vinnola, INL (Anthony.Vinnola@inl.gov)

74. David L. Price, DOE (David.Price@science.doe.gov)

75. Kivanc Ekici, UT (ekici@utk.edu)

76. Rao Arimilli, UT (arimilli@utk.edu)

77. Arthur Ruggles, UT (aruggles@utk.edu)

78. R. T. Primm, Primm Consulting (trentprimm@primmconsultingllc.com)

79. Shane Jacobs, B\&W (sajacobs@babcock.com)

80. Scott Nagley, B\&W (sgnagley@babcock.com) 